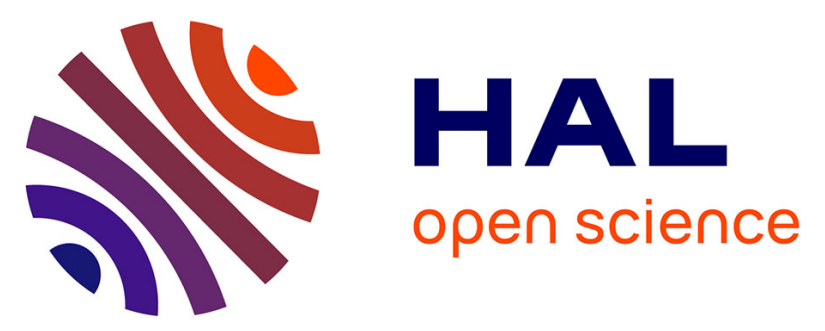

\title{
The African upper mantle and its relationship to tectonics and surface geology
}

Keith Priestley, Dan Mckenzie, Eric Debayle, Sylvana Pilidou

\section{To cite this version:}

Keith Priestley, Dan Mckenzie, Eric Debayle, Sylvana Pilidou. The African upper mantle and its relationship to tectonics and surface geology. Geophysical Journal International, 2008, 175 (3), pp.11081126. 10.1111/j.1365-246X.2008.03951.x . hal-00656879

\section{HAL Id: hal-00656879 https://hal.science/hal-00656879}

Submitted on 8 Nov 2021

HAL is a multi-disciplinary open access archive for the deposit and dissemination of scientific research documents, whether they are published or not. The documents may come from teaching and research institutions in France or abroad, or from public or private research centers.
L'archive ouverte pluridisciplinaire HAL, est destinée au dépôt et à la diffusion de documents scientifiques de niveau recherche, publiés ou non, émanant des établissements d'enseignement et de recherche français ou étrangers, des laboratoires publics ou privés.

\section{(c)(1)}

Distributed under a Creative Commons Attribution| 4.0 International License 


\title{
The African upper mantle and its relationship to tectonics and surface geology
}

\author{
Keith Priestley, ${ }^{1}$ Dan McKenzie, ${ }^{1}$ Eric Debayle ${ }^{2}$ and Sylvana Pilidou ${ }^{1, *}$ \\ ${ }^{1}$ Bullard Laboratories, University of Cambridge, Cambridge, UK. E-mail: keith@madingley.org \\ ${ }^{2}$ Ecole et Observatoire des Sciences de la Terre, Université Louis Pasteur, Strasbourg, France
}

Accepted 2008 August 22. Received 2008 August 20; in original form 2008 January 26

\begin{abstract}
SUMMAR Y
This paper focuses on the upper-mantle velocity structure of the African continent and its relationship to the surface geology. The distribution of seismographs and earthquakes providing seismograms for this study results in good fundamental and higher mode path coverage by a large number of relatively short propagation paths, allowing us to image the $S V$-wave speed structure, with a horizontal resolution of several hundred kilometres and a vertical resolution of $\sim 50 \mathrm{~km}$, to a depth of about $400 \mathrm{~km}$. The difference in mantle structure between the Archean and Pan-African terranes is apparent in our African upper-mantle shear wave model. High-velocity (4-7 per cent) roots exist beneath the cratons. Below the West African, Congo and Tanzanian Cratons, these extend to $225-250 \mathrm{~km}$ depth, but beneath the Kalahari Craton, the high wave speed root extends to only $\sim 170 \mathrm{~km}$. With the exception of the Damara Belt that separates the Congo and Kalahari Cratons, any high-speed upper-mantle lid below the Pan-African terranes is too thin to be resolved by our long-period surface wave technique. The Damara Belt is underlain by higher wave speeds, similar to those observed beneath the Kalahari Craton. Extremely low $S V$-wave speeds occur to the bottom of our model beneath the Afar region. The temperature of the African upper mantle is determined from the $S V$-wave speed model. Large temperature variations occur at $125 \mathrm{~km}$ depth with low temperatures beneath west Africa and all of southern Africa and warm mantle beneath the Pan-African terrane of northern Africa. At $175 \mathrm{~km}$ depth, cool upper mantle occurs below the West African, Congo, Tanzanian and Kalahari Cratons and anomalously warm mantle occurs below a zone in northcentral Africa and beneath the region surrounding the Red Sea. All of the African volcanic centres are located above regions of warm upper mantle. The temperature profiles were fit to a geotherm to determine the thickness of the African lithosphere. Thick lithosphere exists beneath all of the cratonic areas; independent evidence for this thick lithosphere comes from the locations of diamondiferous kimberlites. Almost all diamond locations occur where the lithosphere is $175-200 \mathrm{~km}$ thick, but they are largely absent from the regions of the thickest lithosphere. The lithosphere is thin beneath the Pan-African terranes of northern Africa but appears to be thicker beneath the Pan-African Damara Belt in southern Africa.
\end{abstract}

Key words: Surface waves and free oscillations; Seismic tomography; Cratons; Africa.

\section{INTRODUCTION}

Africa is a very 'old' continent, with almost the whole of its landmass underlain by Precambrian basement. Much of the continent was assembled in the Proterozoic and has been largely stable since that time, and therefore, the African lithosphere contains an

\footnotetext{
*Now at: the Cyprus Geological Survey, Lefkosia, Cyprus.
}

important record of the Earth's early history that is largely free from more recent overprinting. The oldest rocks are found in the four main cratons (Fig. 1): the Kalahari, Congo, Tanzania and West African Cratons. A network of mobile belts, primarily of Pan-African age (650-450 Myr) surround the cratons (Kennedy 1964, 1996; Shackleton 1976; Cahen et al. 1984). A major Early Cretaceous rift and fracture system (Fig. 1) divides the African plate into a western block, an Arabian-Nubian block and an Austral block (Guiraud \& Maurin 1992). The opening of the Atlantic Ocean was the dominant driving force for the western and Austral 


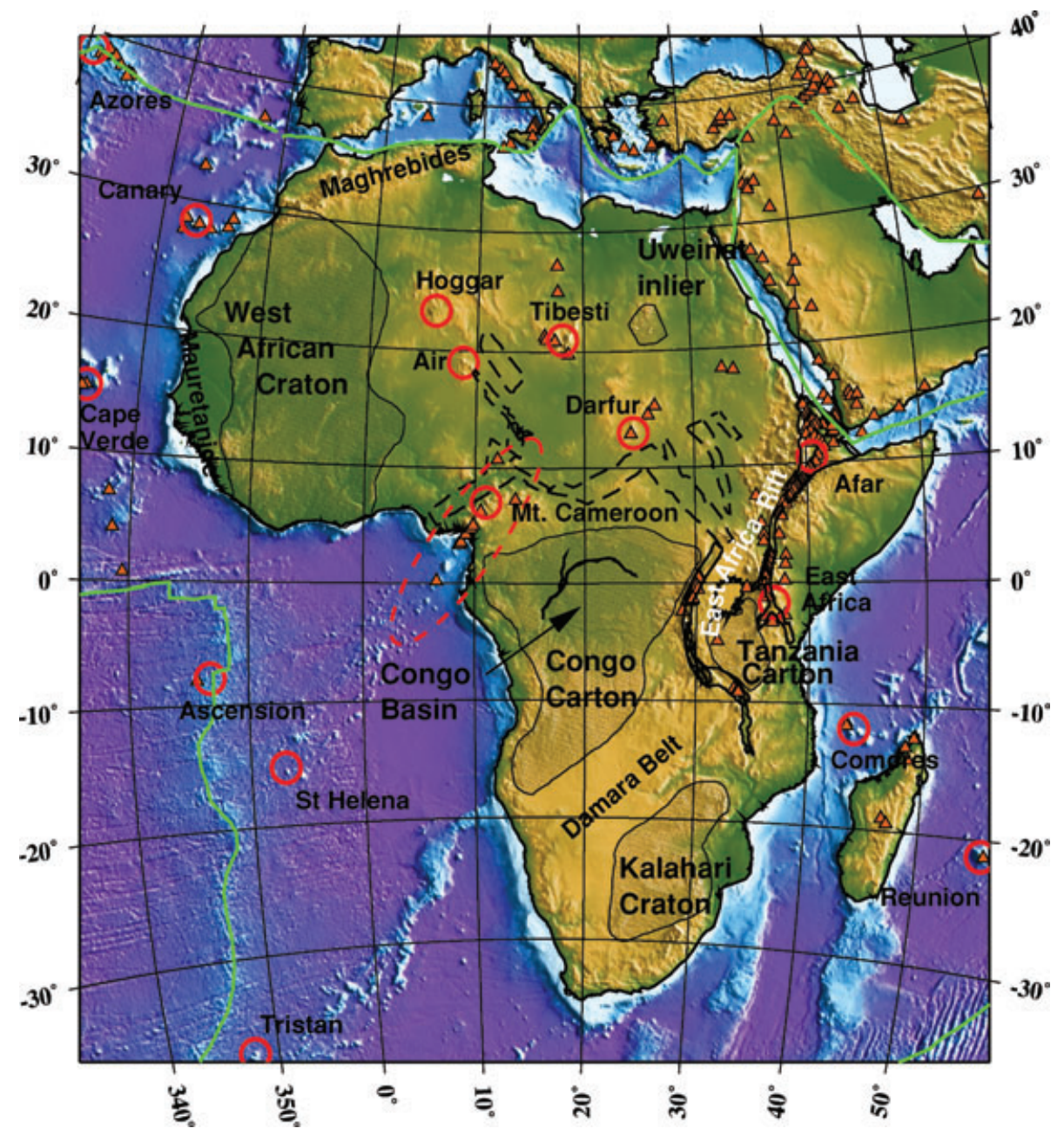

Figure 1. Topographic/tectonic map of the African continent. Small red triangles denote locations of individual volcanoes and red circles denote volcanic centres thought to be related to mantle plumes. The stippled regions denote the surface manifestation of the Archean cratons. Dashed black lines indicate the location of the Late Cretaceous rift system in Central Africa and solid black lines the location of the East Africa rift. The dashed red oval denotes the location of the Cameroon Line. The solid green lines denote plate boundaries.

blocks, whereas the Arabian-Nubian block probably moved in response to the opening of the Indian Ocean and to the evolution of the Tethyan margin (Guiraud \& Maurin 1992). Most of the rifts and faults are located within the mobile zones of the Pan-African belts.

The most recent tectonic events affecting Africa are the East African rift (Fig. 1) that initiated 30-40 Ma (Burke 1996) and now extends from Afar to Mozambique and the Maghrebides Belt of NW Africa that is related to the Alpine orogeny. The African plate contains a large number of volcanic centres that are thought to be related to mantle plumes (Fig. 1), although there is no agreement as to the number of plumes. During the Tertiary, Africa has experienced greater uplift than has any other continent (Bond 1979), and much of it now stands above $1 \mathrm{~km}$. Much of southern Africa is characterized by high topography, referred to by Nyblade \& Robinson (1994) as the African superswell. The large-scale pattern of broad basins separated by irregular swells, first pointed out by Holmes (1944), may be a consequence of the dynamic effects of mantle convection acting below the African lithosphere (e.g. Burke \& Wilson 1972; McKenzie \& Weiss 1975; England \& Houseman 1984), although others disagree with the view that such a pattern exists (Doucoure \& deWit 2003). Studies of absolute plate motion show that at present, the African plate is almost stationary, and this may be the reason that Africa's more recent tectonics have been dominated by vertical motions (Burke \& Wilson 1972; Hartley et al. 1996).

The upper-mantle shear-wave velocity structure of Africa is the focus of this paper. There have been a number of prior, large-scale surface wave studies of Africa (e.g. Dorbath \& Montagner 1983; Hadiouche \& Jobett 1988; Ritsema \& van Heijst 2000; Debayle et al. 2001; Sebai et al. 2006; Pasyanos \& Nyblade 2007), the majority of which rely on fundamental mode observations. Our study uses a large, multimode surface wave data set to investigate the $S V$ wave speed heterogeneity of the upper mantle beneath Africa. We present a high-resolution, 3-D tomographic image of the upper mantle beneath Africa that displays significant shear velocity features to depths of 200-250 km, most of which correspond to the Archean cratons. Below $\sim 250 \mathrm{~km}$ depth, the correlation of upper-mantle structure with surface tectonics is greatly reduced.

After briefly summarising the data and our analysis procedure, we present our African upper-mantle model. We then use the relationship between shear velocity and temperature of Priestley \& McKenzie (2006) to derive the upper-mantle temperature field beneath Africa and a model for the African lithosphere. Finally, we discuss the upper-mantle structure of Africa in light of the surface 

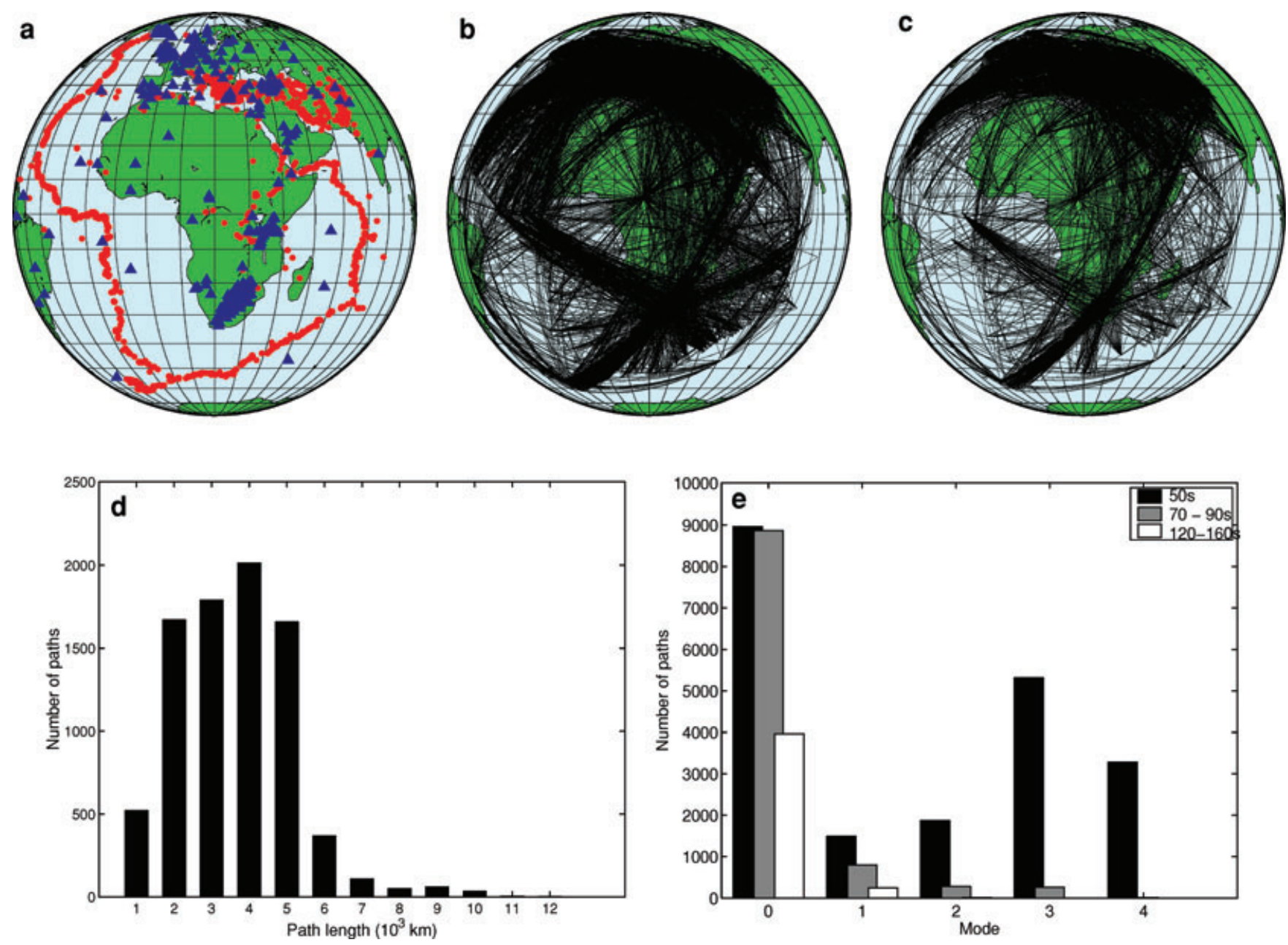

Figure 2. Summary of the data used in the surface wave tomography study. (a) Distribution of stations (blue triangles) and events (red dots), (b) fundamental mode path coverage, (c) higher mode path coverage, (d) distribution of propagation path lengths and (e) modal composition of the data.

geology and tectonics. An assessment of the reliability of our African model is given in the Appendix.

\section{SURFACE WAVE DATA AND A NALYSIS}

Using the Global CMT catalogue, we analysed earthquakes that occurred between 1977 and 2002; however, because of the great expansion of the GDSN in the mid-1990s, most of the data are from the period since 1994. Seismograms are taken from recordings at permanent stations of the IRIS-IDA, IRIS-USGS, GEOSCOPE and GEOFON networks, plus INSU and IRIS-PASSCAL temporary seismograph deployments in Africa and the surrounding region. The distribution of stations and events providing seismograms for this study (Fig. 2a) results in good fundamental (Fig. 2b) and higher mode (Fig. 2c) path coverage by a large number of relatively short propagation paths (Fig. 2d). Since most of the earthquakes we studied are located on the plate boundaries surrounding Africa, we avoid long oceanic paths, which decrease the resolution of global tomography models (Ritzwoller et al. 2002). Although many of our measurements are of the fundamental mode (Figs $2 b$ and e), our analysis also includes a large number of higher mode observations (Figs 2c and e).
Our tomographic model is derived by first inverting the individual surface waveforms in the $50-160 \mathrm{~s}$ period range for a path-average $S V$ model using the automated version (Debayle 1999) of the Cara \& Lévêque (1987) technique. The advantage of this method is that higher mode information can be retrieved from the seismograms, thus improving the resolution in the upper mantle. In applying the Cara \& Lévêque (1987) technique, we use a reference model that has a crust formed by averaging the crustal portion of 3SMAC (Nataf \& Ricard 1996) along the path (Fig. 3). Above a mantle derived from PREM (Dziewonski \& Anderson 1981) by replacing the upper-mantle discontinuities in PREM at 220 and $400 \mathrm{~km}$ depth, with gradients. This is important because the Lehmann discontinuity in PREM at $220 \mathrm{~km}$ is not likely to be a global feature (e.g. Gu et al. 2001). If it were introduced at this stage in the reference model, it would not be removed in the later stages of the inversion procedure. A velocity gradient provides a more flexible parametrization of the Lehmann discontinuity: the gradient accounts for the vertical smoothing of surface waves and can be removed or increased, depending on the local strength of any eventual Lehmann discontinuity in the upper-mantle model.

Since many of the paths are similar, we cluster measurements for paths with epicentres within a $2^{\circ}$ spherical cap recorded at the same station, while ensuring that no path belongs to more than one cluster. For each cluster, we determine each depth's average 


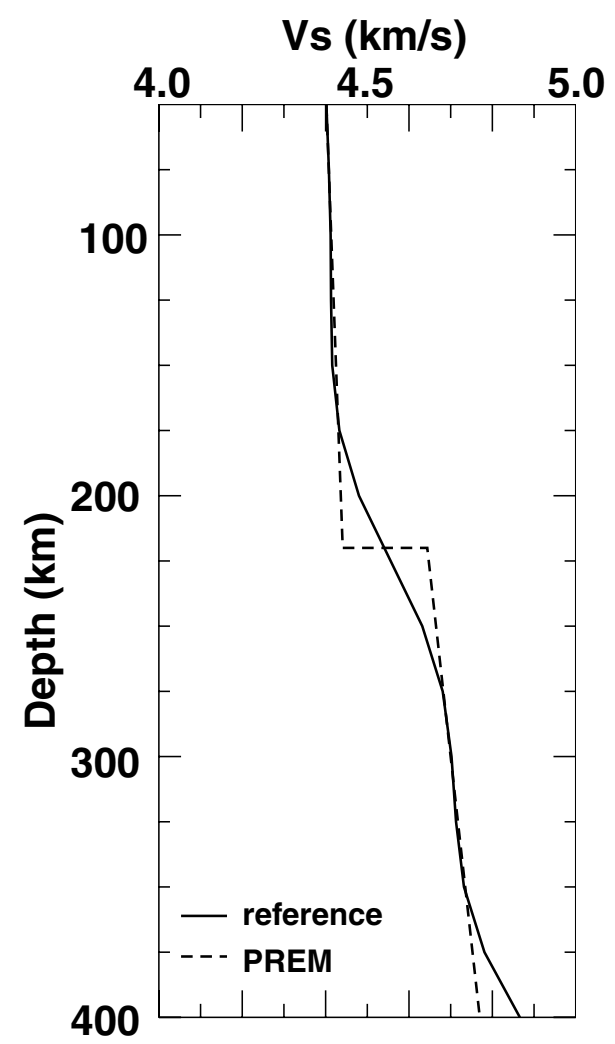

Figure 3. Reference model used in this study compared with the global reference velocity model PREM (Dziewonski \& Anderson 1981).

shear-wave velocity profile and its error from the mean and the standard deviation of the mean of the shear wave velocity of its component paths. The errors obtained using this approach are generally larger than the a posteriori errors, which are calculated for each individual path of a cluster, from the waveform inversion. However, the errors determined in the clustering procedure are likely to be more realistic, as they reflect measurement errors between multiple path-average measurements along repeatedly sampled propagation paths. This clustering approach was previously followed by Debayle et al. (2005) and Maggi et al. (2006) and is described in detail in Maggi et al. (2006).

The average velocity models are then combined in a tomographic inversion to obtain the 3-D $S V$-wave speed structure and the azimuthal anisotropy, as a function of depth, using the technique of Montagner (1986) as implemented by Debayle \& Sambridge (2004) for massive data sets. The lateral smoothness of the 3-D model is controlled in the tomographic inversion by a Gaussian a priori covariance function, defined by a scale length $L_{\text {corr }}$ and a standard deviation $\sigma . L_{\text {corr }}$ defines the distance to which adjacent points of the model are correlated and acts as a spatial filter; $\sigma$ controls the amplitude of the perturbation in Earth structure allowed in the inversion. Implicit in our analysis are the assumptions that the surface wave can be represented as a sum of modes propagating independently with no coupling, and that they do so along the great circle path from the epicentre to the recording station. These assumptions are valid for the frequency band and mode range of the surface waves we use (Woodhouse 1974; Kennett 1995; Marquering et al. 1996; Ritzwoller et al. 2002). Details of the method we employ can be found in Cara \& Lévêque (1987), Debayle (1999), Debayle \& Kennett (2000a), Debayle \& Sambridge (2004) and Priestley et al. (2006a).

\section{THE TOMOGRAPHIC MODEL}

Figs 4 and 5 show maps and cross-sections of the 3-D $S V$-wave speed structure for Africa. $S V$-wave speed maps give a much clearer indication of the properties at depth than do group and phase velocity maps, which represent a weighted average of the Earth structure over a frequency-dependent depth interval. The depths shown in the four maps (Fig. 4) were chosen to facilitate a comparison with the models of Ritsema \& van Heijst (2000) and Pasyanos \& Nyblade (2007). Our model was obtained using $L_{\text {corr }}=400 \mathrm{~km}$, for both velocity heterogeneity and azimuthal anisotropy, $\sigma=0.05 \mathrm{~km} \mathrm{~s}^{-1}$ for the velocity perturbation and $\sigma=0.003 \mathrm{~km} \mathrm{~s}^{-1}$ for the azimuthal anisotropy variation. These values favour a smooth model, considering our shortest wavelengths (about $200 \mathrm{~km}$ at $50 \mathrm{~s}$ period) and dense path coverage. Sieminski et al. (2004) show that by using a dense path coverage of relatively short paths and assuming ray theory, it is possible to detect heterogeneity with length scales smaller than the wavelength of the data set. The discussion below shows that the chosen values of $L_{\text {corr }}$ and $\sigma$, the path density (Figs $2 \mathrm{~b}$ and c) and the frequency and modal composition of our data (Figs $2 d$ and e) allow us to resolve structures with horizontal wavelengths of several hundred kilometres in the uppermost $\sim 400 \mathrm{~km}$ of the model. This agrees with the lateral resolution that can be expected when considering the 'influence zone' over which surface waves are coherent in phase and which is identified as approximately one third of the first Fresnel zone (Yoshizawa \& Kennett 2002; Sieminski et al. 2004).

In the 100-150-km-depth range (Figs $4 \mathrm{a}$ and b), the $S V$ heterogeneity is strong and correlates with tectonic patterns seen in the surface geology. Prominent high-velocity structures with positive $S V$-wave speed perturbations of 6 per cent or more with respect to our reference model (Fig. 3) occur beneath the West African, Congo, Tanzania and Kalahari Cratons. Low-velocity structures with negative $S V$-wave speed perturbations of -7 per cent or more occur beneath northcentral Africa, the Afar, the Red Sea and the adjacent parts of Arabia. Cross-sections through the model (Fig. 5) show that the margins of the high-velocity features beneath the cratons can be quite sharp.

Although we include azimuthal anisotropy in the tomographic inversion, we do not include the results in Fig. 4. The reason for including azimuthal anisotropy in the tomographic inversion is that there can be coupling between $S V$-wave speed heterogeneity and azimuthal anisotropy (Pilidou et al. 2004). We have checked that azimuthal anisotropy does not bias the $S V$-heterogeneity pattern in our Africa model by performing tomographic inversions that include and exclude azimuthal anisotropy. The maps shown in Fig. 4 are those from the inversions including azimuthal anisotropy. We find that for Africa, the magnitude of azimuthal anisotropy (Fig. 6) is stronger and more spatially complex at shallow depths corresponding to the lithosphere and weaker and simpler at deeper depths corresponding to the asthenosphere below. Because the motion of Africa is slow and strains are small, simple shear probably leads to weak azimuthal anisotropy, consistent with our observations. This azimuthal anisotropy pattern agrees with the conclusions of Debayle et al. (2005) that deformation beneath continents on a slow-moving plate is insufficient to form a sheared layer with significant azimuthal anisotropy.

Although we have confidence in the general depth variation pattern of the magnitude of azimuthal anisotropy (Fig. 6), we are much less sure of the spatial variation. Priestley et al. (2006a) tested the azimuthal anisotropy resolution in a tomographic model for Asia, using a similar but larger surface-wave data set, and concluded that 


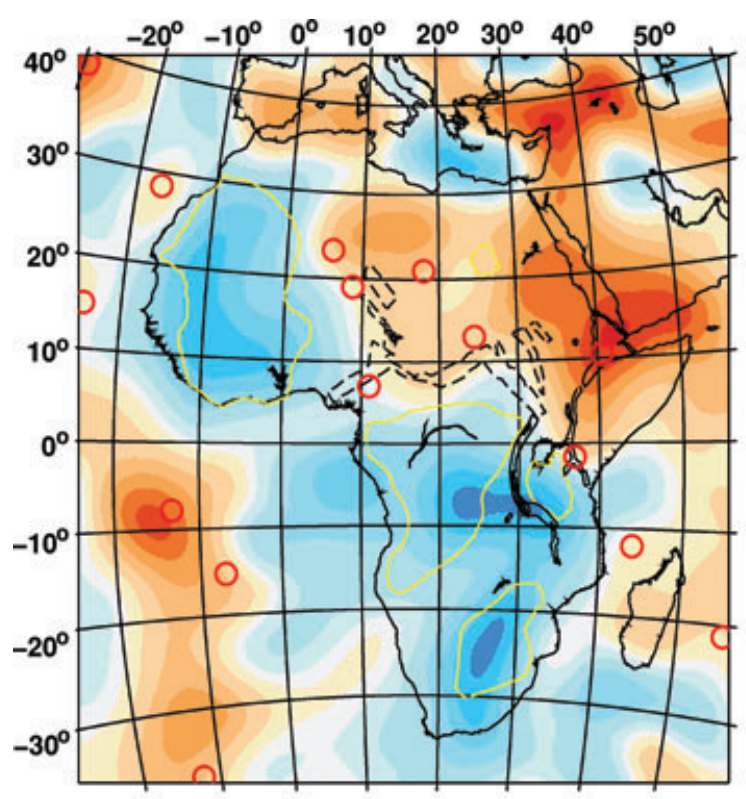

$\delta \mathrm{Vs} \% 100 \mathrm{~km}(\mathrm{Vsref}=4.412 \mathrm{~km} / \mathrm{s})$

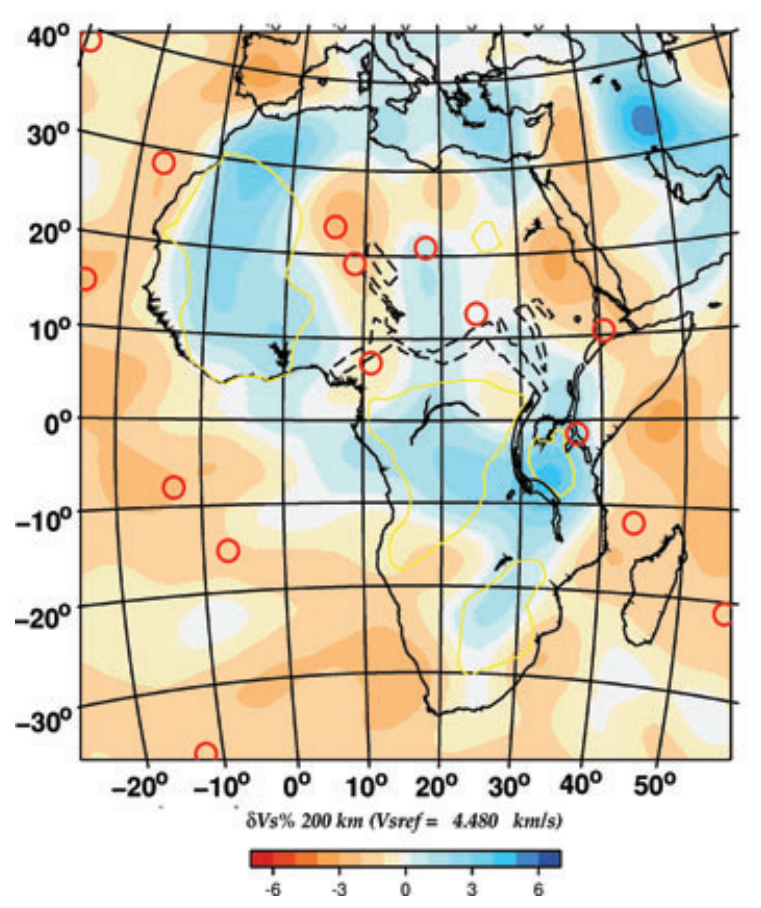

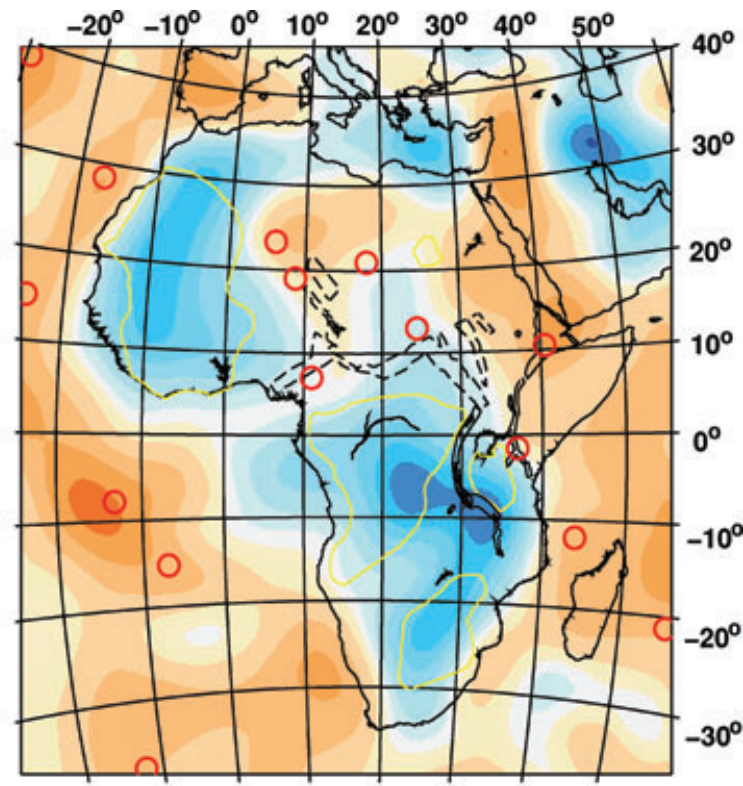

$\delta \mathrm{Vs} \% 150 \mathrm{~km}(\mathrm{Vsnef}=4.416 \mathrm{~km} / \mathrm{s})$

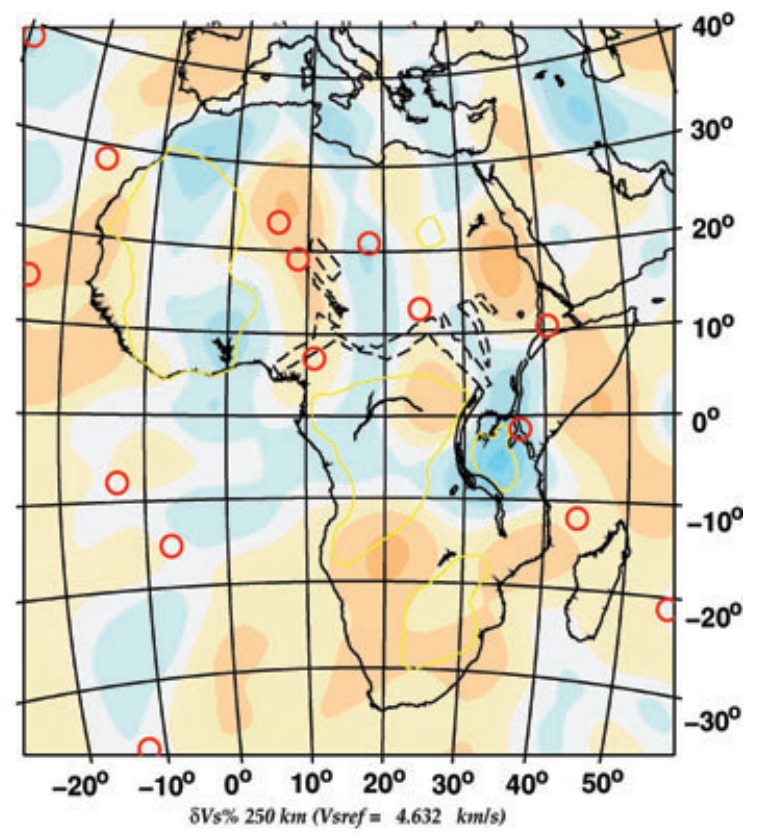

Figure 4. The variation in seismic wave speed at four depths beneath Africa. The scale below the $200 \mathrm{~km}$ depth map shows the percent deviation from the reference model shown in Fig. 3. The red circles denote postulated plume locations, and the surface manifestations of the cratons are indicated by the yellow contours.

the magnitude and direction of the anisotropy pattern are in general well reconstructed in areas of the model where azimuthal path coverage is good and the spatial variation in azimuthal anisotropy is smooth. However, in regions of rapid change in the direction of azimuthal anisotropy, the horizontal smoothing introduced by the long-period surface waves leads to a pattern that can be locally wrong in both amplitude and direction. Thus, the anisotropic pattern obtained with surface waves is meaningful where the anisotropy varies slowly with respect to the seismic wavelength but can be locally wrong in regions where changes in anisotropic direction occur over distances much smaller than a wavelength. For this reason, we have not included the spatial pattern of azimuthal anisotropy on the maps in Fig. 4 and will not discuss the azimuthal anisotropy of our model further.

There are a number of factors in both stages of the analysis, which influence the accuracy and resolution of the tomographic model. In the first stage of the analysis, the reliability of the path-average models is affected by non-great circle propagation, mode coupling, the choice of reference model and poor knowledge of the parameters that are not 

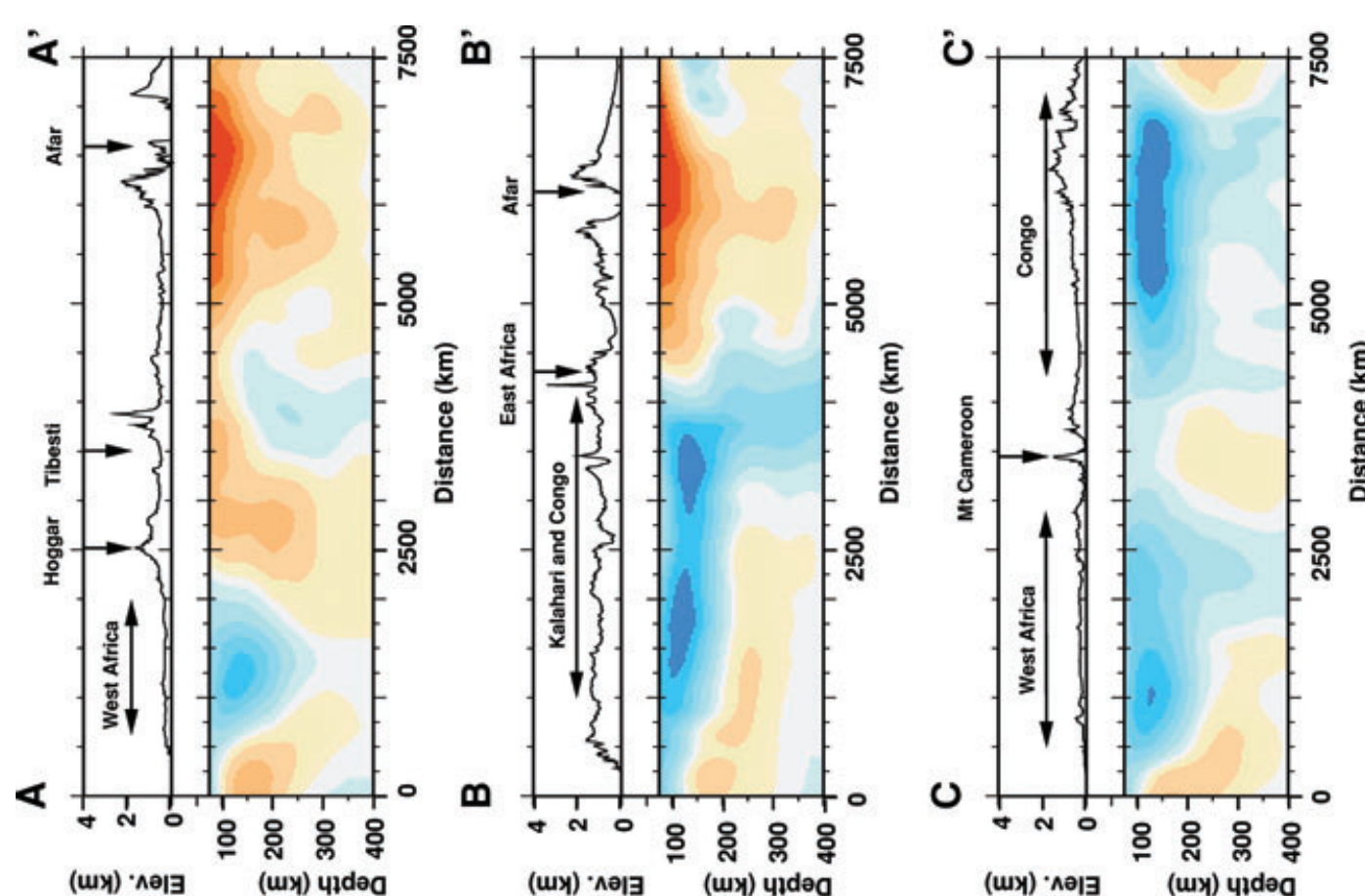

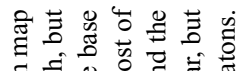

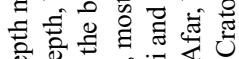

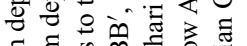

छี छ की

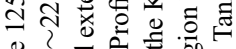

‡ $ᄋ$ 可

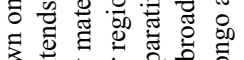

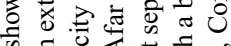

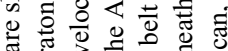

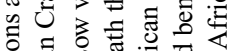

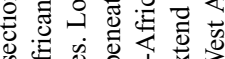

的《昰度

की

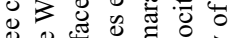

至语言觉

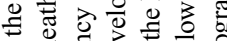

ए ए

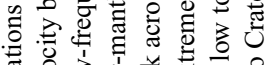

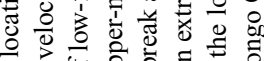

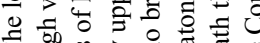

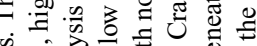

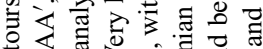

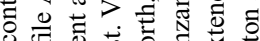

范范要

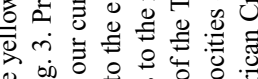

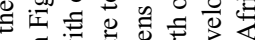

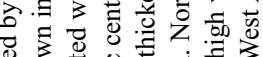

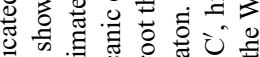

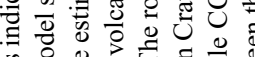

की

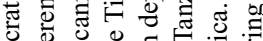

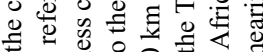

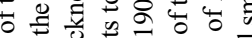

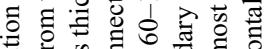

跑

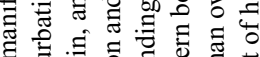

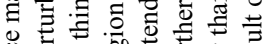

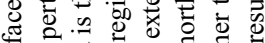

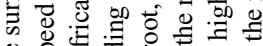

क्ष

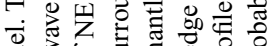

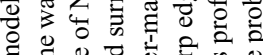

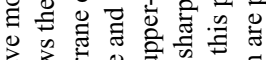

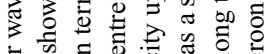

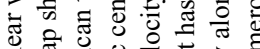

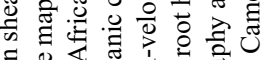

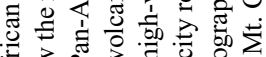

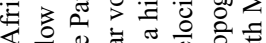

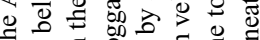

记

के फू

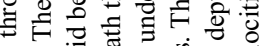

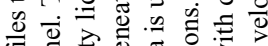

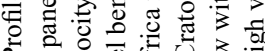

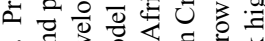

ம

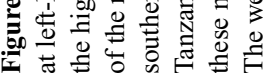




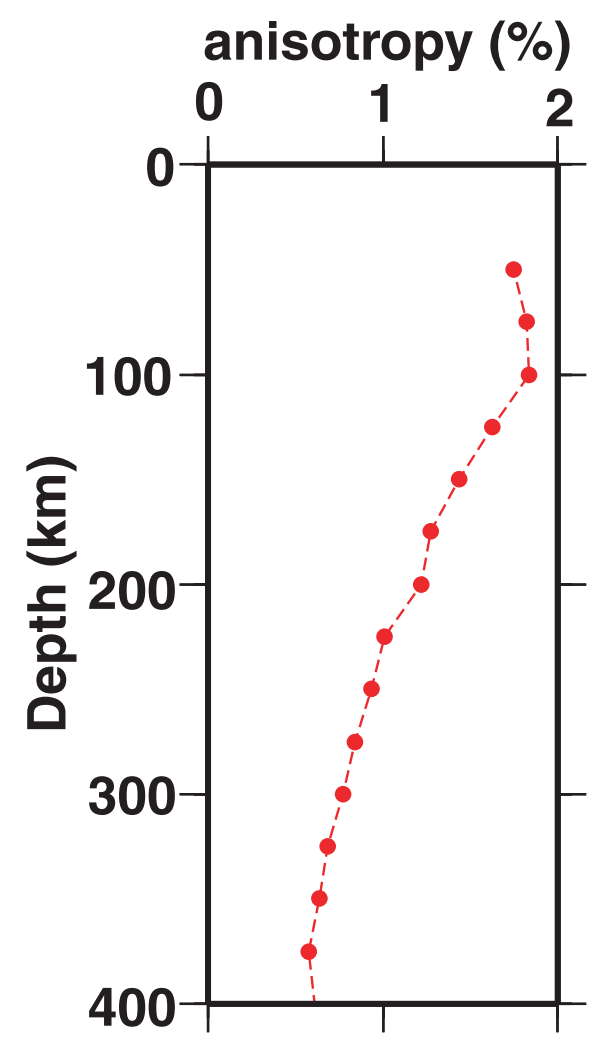

Figure 6. Mean amplitude of azimuthal anisotropy versus depth for the continental part of our African model.

determined by the inversion (e.g. earthquake source parameters and crustal structure). Errors resulting from assuming the great-circle approximation are minimized by choosing relatively short propagation paths (Ritzwoller et al. 2002; Debayle \& Sambridge 2004). Artefacts resulting from ignoring mode coupling are minimized by considering only the fundamental and first four higher modes for periods greater than $50 \mathrm{~s}$ (Marquering et al. 1996). Cara \& Lévêque (1987) show that, for their waveform inversion technique, the 1-D velocity structure obtained from the inversion is weakly dependent on the reference model. We have explored the effect of the reference model on the inversion outcome in previous studies and found that the result is negligible for a range of commonly accepted reference earth models (Pilidou et al. 2004).

Errors in earthquake source parameters will cause errors in the path-average velocity models determined in the first stage of the analysis. However, if the path density and azimuthal coverage are good, the effects of the mislocation in the second stage of the analysis will be small and restricted to the earthquake source region (Ritzwoller \& Levshin 1998; Maggi \& Priestley 2005). Debayle $\&$ Kennett (2000b) show that reasonable errors in crustal thickness have little effect on the mantle structure below 100-125 km depth. In similar surface wave studies (Pilidou et al. 2004; Priestley et al. 2006a), we have tested the effect of using the CRUST2.0 (http://mahi.ucsd.edu/Gabi/rem.dir/crust/crust2.html) model in place of the 3SMAC (Nataf \& Ricard 1996) crustal model used here and have found little difference in the resulting uppermantle models. In addition, Pasyanos \& Nyblade (2007) studied short-period fundamental-mode surface wave propagation in Africa and concluded that the 3SMAC model predicted the short-period group velocities better than did CRUST2.0. There is no indication that there are large thickness variations in the African crust similar to those observed in South America (i.e. Swenson et al. 2000) or Central Asia (i.e. Mitra et al. 2005); so, errors in upper-mantle wave speeds resulting from uncertainties in crustal thickness are probably small.

Assuming that we have correctly estimated the average velocity models and their errors in the first stage of the analysis, the reliability and resolution of the 3-D tomographic model determined in the second stage of the analysis are primarily the result of the validity of the great-circle approximation, the path coverage, the frequency and modal-makeup of the surface waves analysed and the smoothing imposed in the tomographic inversion. To assess the resolution of our model, we conduct a number of synthetic tests whose results are discussed in the Appendix.

\section{COMPARISON TO RECENT AFRICAN SHEAR WAVE MODELS}

There are several surface-wave tomography models for Africa, most of which are for southern part of the continent. Here we compare our results to three similar-scale Africa models - those of Ritsema \& van Heijst (2000), Sebai et al. (2006) and Pasyanos \& Nyblade (2007).

Ritsema \& van Heijst (2000) measured fundamental-mode Rayleigh-wave phase velocities in the period range 40-200 s, using the mode-branch stripping method (Van Heijst \& Woodhouse 1999). After correcting the phase velocities for crustal effects, using model CRUST 5.1 (Mooney et al. 1998), they inverted the phase velocity data for upper-mantle shear wave velocity but not azimuthal anisotropy. Their model has a lateral resolution of about $500 \mathrm{~km}$, similar to that in Fig. 4, and a depth resolution in the upper $250 \mathrm{~km}$ of $\sim 50 \mathrm{~km}$ but with somewhat poorer resolution at larger depths. At $100-150 \mathrm{~km}$ depth, our model is similar to the Ritsema \& van Heijst (2000) model. Both show $\sim 6$ per cent high-velocity perturbation, extending beneath most of southern Africa, with no clear distinction between the Congo, Tanzania and Kalahari Cratons. A high-velocity band extends northwards from Central Africa, prominent at $150 \mathrm{~km}$ in both models and stronger at $100 \mathrm{~km}$ depth in the Ritsema \& van Heijst (2000) model than in our model. Both show shallow low velocity beneath the Afar region. Their model has weak, positive wave speed perturbations extending to somewhat deeper depths beneath the cratons than in our model, but both show an abrupt northern edge to the Tanzanian Craton. The fundamental mode constraints in our study (Fig. 2e) are similar to those in the Ritsema \& van Heijst (2000) model (see their Fig. 3), and the difference in the deep structure beneath the cratons in the two probably results from the improved resolution at depths, resulting from the inclusion of higher-mode observations in our analysis.

Sebai et al. (2006) obtained fundamental-mode phase velocities in the period range 45-250 s from 2900 Rayleigh and 1050 Love wave seismograms, using the roller-coaster technique (Beucler et al. 2003). To improve path coverage, they analyse seismograms from earthquakes in the Pacific, thus including significantly longer propagation paths than ones we used. Sebai et al. (2006) invert their phase velocity measurements for both $S V$-wave speed and anisotropy. Although they display their model at slightly different depths than those we plot in Fig. 4, the similarities between the two models are clear, at shallow depths. Both show strong high-velocity perturbations beneath most of southern and western Africa. Differences occur primarily in the deeper parts of the models, where the Sebai et al. (2006) model suggests weak highvelocity features beneath southern Africa at $280 \mathrm{~km}$ depth, whereas 
our model indicates no distinction between the continental structure and the adjacent ocean at this depth. Again, these differences in the deeper parts of the models probably reflect the improved depth resolution in the deeper part of our model provided by the inclusion of the higher mode surface wave measurements.

Pasyanos \& Nyblade (2007) measure 7-100 s period fundamental mode Rayleigh- and Love-wave group velocities for a large number of paths crossing Africa and Arabia. From these, they construct Rayleigh- and Love-wave group velocity curves as a function of latitude and longitude and then use a grid search procedure to invert for the best 1-D isotropic velocity model, fitting each dispersion curve. Pasyanos \& Nyblade (2007) use the continental model ak135 (Kennett et al. 1995) as a reference model; so, the velocity perturbations in their maps do not compare directly with those in Fig. 4. Both models show high velocities beneath the cratons and low velocities beneath Afar, but the details are different. In the Pasyanos \& Nyblade (2007) model, a large area of the ocean surrounding southern Africa has a 4-7 per cent higher velocity at $150-200 \mathrm{~km}$ depth, whereas in our model, the higher velocities are primarily restricted to the continent. There are subtle differences in the cratonic roots between the two models. The high-velocity root beneath the West African Craton extends farther north in our model than in the Pasyanos \& Nyblade (2007) model. Our model shows a thick high-velocity root beneath both the Congo Basin of the Congo Craton and below Tanzanian Craton, neither of which has a thick high- velocity root in the Pasyanos \& Nyblade (2007) model.

It is impossible to assess the reasons for these differences from the information provided in Pasyanos \& Nyblade (2007). They claim, based on the wavelengths of their data, that in well-sampled regions at intermediate periods $(20-40 \mathrm{~s})$, the resolution approaches $1^{\circ}$ whereas the resolution of periods sensitive to mantle depths ( $>60 \mathrm{~s}$ ) can be as good as $2^{\circ}$. However, they provide no evidence to substantiate this statement. We return to this below when we discuss the details of our model. We believe our upper-mantle model is more reliable than that of Pasyanos \& Nyblade (2007) because of the lower-frequency fundamental mode data and the higher mode data constraining our model compared with the higher-frequency fundamental mode data constraining the Pasyanos \& Nyblade (2007) model. In addition, Pasyanos \& Nyblade (2007) have performed an isotropic inversion of Love and Rayleigh wave dispersion, without considering radial anisotropy, a procedure that can lead to artefacts (Anderson \& Dziewonski 1983), and they have used group velocity data whose sensitivity kernels are compressed near the surface compared with phase velocity kernels (Rodi et al. 1975) and have inverted short period surface wave data, without considering lateral refraction.

\section{MANTLE TEMPERATURE AND LITHOSPHERIC THICKNESS BENEATH AFR I C A}

The high-velocity upper-mantle seismic lid is often taken as the 'lithosphere', but lithosphere is a geodynamic concept, denoting the outer shell of the Earth that forms the rigid plates that translate in plate tectonics and in which heat is transported by conduction. Neither the mechanical properties nor the mode of heat transport has a direct influence on the seismic wave speed. Various ways of defining the lithosphere from seismic tomography have been proposed, for example, the depth to the strongest negative velocity gradient (e.g. Nishimura \& Forsyth 1989; Debayle \& Kennett 2000a) or the depth to the centre of the negative velocity gradient (e.g. Weeraratne et al. 2003). The difficulty in using seismology to map lithospheric thickness arises because the base of the lithosphere does not correspond to a step in temperature or composition and is, therefore, not associated with a significant change in seismic velocity. What does change rapidly over a limited vertical distance at the base of the lithosphere is the temperature gradient.

McKenzie et al. (2005) demonstrated that the mechanical behaviour of both the oceanic and continental lithosphere depends primarily on temperature. Priestley \& McKenzie (2006) used the correspondence between the $V_{S}$ and the thermal structure of the Pacific plate to obtain an empirical relationship between the temperature and $S V$-wave speed for the oceanic lithosphere. At depths greater than about $50 \mathrm{~km}$, the ocean lithosphere consists of fertile garnet peridotite, whereas the upper mantle beneath the cratons consists of harzburgite, formed from peridotite by the removal of 20-25 per cent melt. However, temperature has the dominant effect on $V_{S}$, and the effect of melt removal on $V_{S}$ is minor, even when 20-25 per cent melt is removed. The velocity of the residual harzburgite after melt removal is only about $0.03 \mathrm{~km} \mathrm{~s}^{-1}$ greater than that of undepleted peridotite (Jordan 1979; Schutt \& Lesher 2006). Thus, the relationship between shear wave speed and temperature, developed for the Pacific lithosphere, can be used to estimate temperature beneath the continents.

The temperature of the African upper mantle was calculated from the $S V$-wave speed model, using the relationship of Priestley \& McKenzie (2006) on a $2^{\circ} \times 2^{\circ}$ grid, at depth intervals of $25 \mathrm{~km}$, starting at $125 \mathrm{~km}$ depth. Temperatures at 125 and $175 \mathrm{~km}$ depth are shown in Fig. 7. At $125 \mathrm{~km}$ beneath the oceanic part of the African plate, lateral temperature variations are small. Low temperatures occur at $125 \mathrm{~km}$ depth beneath West Africa and all of southern Africa. At $175 \mathrm{~km}$ depth, most of the African mantle is marginally cooler than the surrounding oceanic mantle at the same depth, except for a zone in northcentral Africa and the region surrounding the Red Sea. Cool upper mantle occurs below the West African, Congo, Tanzanian and Kalahari Cratons at $175 \mathrm{~km}$ depth. All of the postulated plumes are located in regions of warm upper mantle compared with the mantle temperatures below the cratons (Fig. 7).

The temperature profiles were fit to a geotherm, calculated using the method of McKenzie et al. (2005). This approach assumes that the thermal structure of the lithosphere is controlled by local processes: heat generation in the crust; transport of heat by conduction through the mechanical boundary layer and transport of heat by advection in the thermal boundary layer. We assume a potential temperature of $1315^{\circ} \mathrm{C}$ for the advecting mantle, a value constrained by the average thickness of the oceanic crust of $7 \mathrm{~km}$. Two factors prevent an accurate determination of the thickness of the lithosphere where it is thin. First, in our surface wave analysis, we fix the crust to that of the 3SMAC model (Nataf \& Ricard 1996) and do not invert for the crustal thickness. Hence, the $S V$-wave speed in the very shallow mantle can be underestimated due to errors in crustal thickness or velocity (Debayle \& Kennett 2000b). For example, if the 3SMAC crust is too thin or too fast, the $S V$-wave speed in the upper mantle will be too slow, leading to an overestimate of the temperature. Second, temperature estimates are more accurate at high temperatures because $\left|\partial V_{S} / \partial T\right|$ increases with increasing temperature. Therefore, only those values of temperature that exceeded $1100^{\circ} \mathrm{C}$ at depths of $125 \mathrm{~km}$ or more are used to obtain the geotherms and to estimate the lithospheric thickness shown in Fig. 8.

Thick lithosphere underlies much of western Africa and most of southern Africa. In the south, the extent of the thick lithosphere 

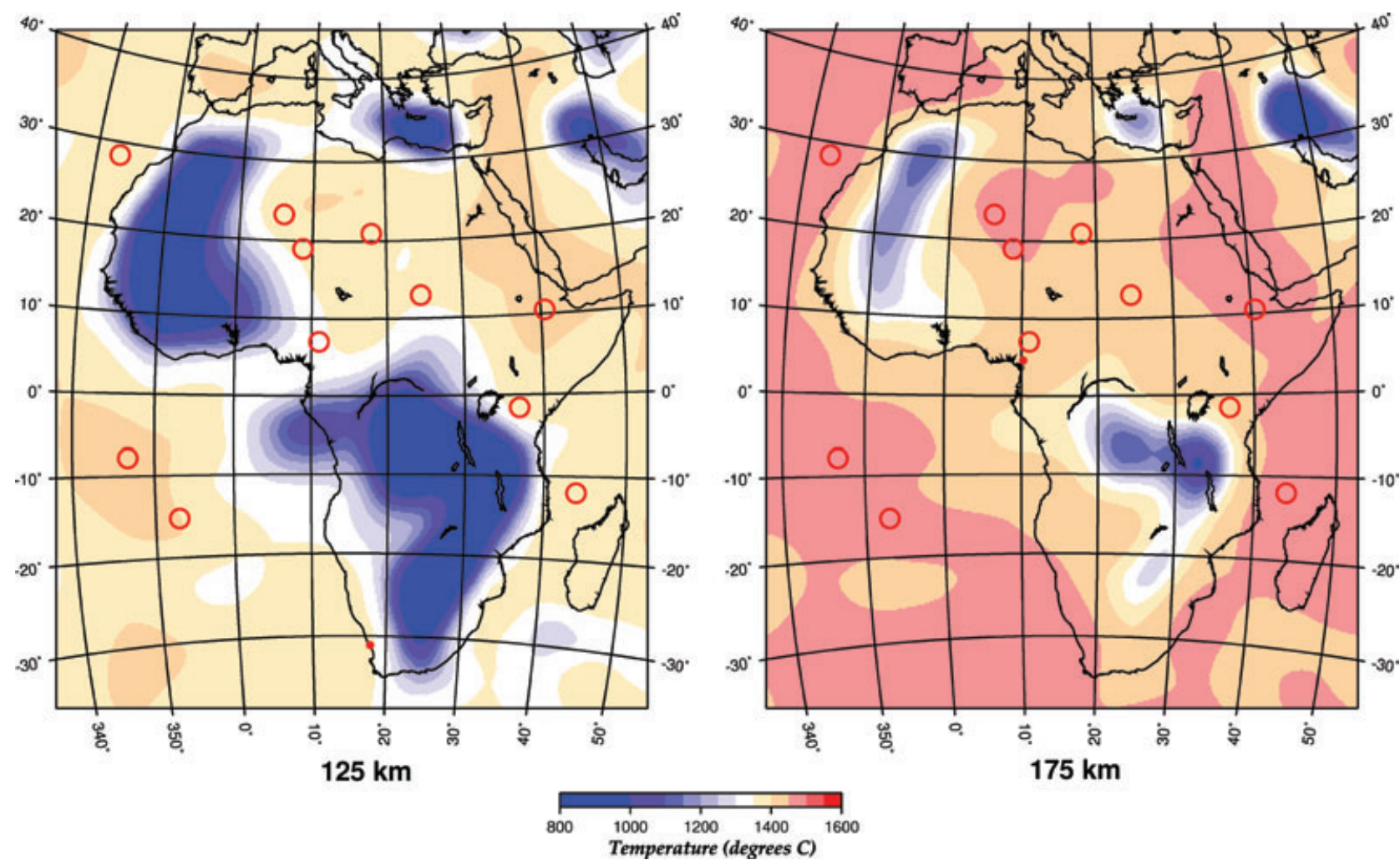

Figure 7. Upper-mantle temperature of the African plate at 125 and $175 \mathrm{~km}$ depth. Red circles denote postulated plume locations. Lateral temperature variations beneath the oceans are small, consistent with the plate model. Cool temperatures occur over wide regions of western and southern Africa at $125 \mathrm{~km}$ depth but below much more restricted regions at $175 \mathrm{~km}$ depth. Most of the African mantle at $175 \mathrm{~km}$ depth is cooler than the mantle of the surrounding ocean at this depth, except for an area in Northcentral Africa and the region including and surrounding the Red Sea.

is significantly different from the distribution of Archean crust mapped at the surface. Thick lithosphere forms a continuous structure beneath the Congo, Tanzania and Kalahari Cratons. However, because of the lateral averaging of the surface waves, we cannot rule out narrow regions of thin lithosphere between the cratons. Fig. (A3) shows that some lateral smearing between the Congo and Kalahari Cratons may occur. Since the areas of thick lithosphere do not correspond directly to the geological extent of the Archean crust and $V_{S}$ provides no age information, Priestley \& McKenzie (2006) refer to these areas of thick lithosphere as continental 'cores'. The fact that the Congo, Tanzania and Kalahari Cratons form a single continental core at present, does not imply they have a common origin - they were probably joined during the assembly of Africa during the Pan-African orogeny (Burke 1996).

Independent estimates of lithospheric thickness come from diamond locations and the mineralogy of mantle nodules. The graphite-diamond transition is at $\sim 140 \mathrm{~km}$ (Kennedy \& Kennedy 1976); hence the occurrence of diamonds in kimberlites denotes regions where the lithosphere is at least $140 \mathrm{~km}$ thick. The diamond localities plotted in Fig. 8 show that most of the diamondiferous kimberlites occur where the lithosphere is thicker than $\sim 140 \mathrm{~km}$. They tend to cluster around the margins of the thick lithosphere and are less prevalent in regions of thickest lithosphere. Such a distribution is not surprising, since diamond-bearing kimberlites require both melt and lithosphere thicker than $\sim 140 \mathrm{~km}$. Since the solidus temperature increases with increasing pressure, less melt is likely to be generated beneath the thickest lithosphere than beneath the regions towards the edges of the cratons where the lithosphere is thinner. Depths from the metamorphic reactions in the mantle nodules provide independent estimates for the lithospheric thickness, and these agree to within $\sim 20 \mathrm{~km}$ of the estimates from seismology (Priestley \& McKenzie 2006).

\section{RELATIONSHIP BETWEEN MANTLE STRUCTURE AND SURFACE GEOLOGY}

Kennedy $(1964,1996)$ pointed out that the entire African continent underwent a major phase of basement re-activation in the Late Precambrian, which resulted in the structural differentiation of the continent into stable cratonic nuclei, surrounded by mobile belts. Kennedy (1964) hesitated to use the term 'orogeny' for this event, as the processes involved appeared to differ from those identified with normal orogenic events and, instead, referred to this period of basement re-activation as the 'Pan-African thermotectonic episode'. He suggested that this event has controlled the subsequent tectonic history of the continent. Black \& Girod (1970) and Thorpe \& Smith (1974) observed that although Cenozoic volcanism is widespread throughout Africa, it is almost wholly confined to the Pan-African terrane. Ashwal \& Burke (1989) interpreted this distribution of Cenozoic volcanism within Africa as indicative of two types of African upper mantle - the cratons being underlain by depleted upper mantle and the Pan-African terranes being underlain by fertile upper mantle. The difference between the cratons and Pan-African terranes is clear in the upper-mantle $S V$-wave speed structure of Africa.

\subsection{The Cratons}

Most of Africa is underlain by Precambrian basement. The oldest rocks are found in the West African, Congo, Tanzania and Kalahari 


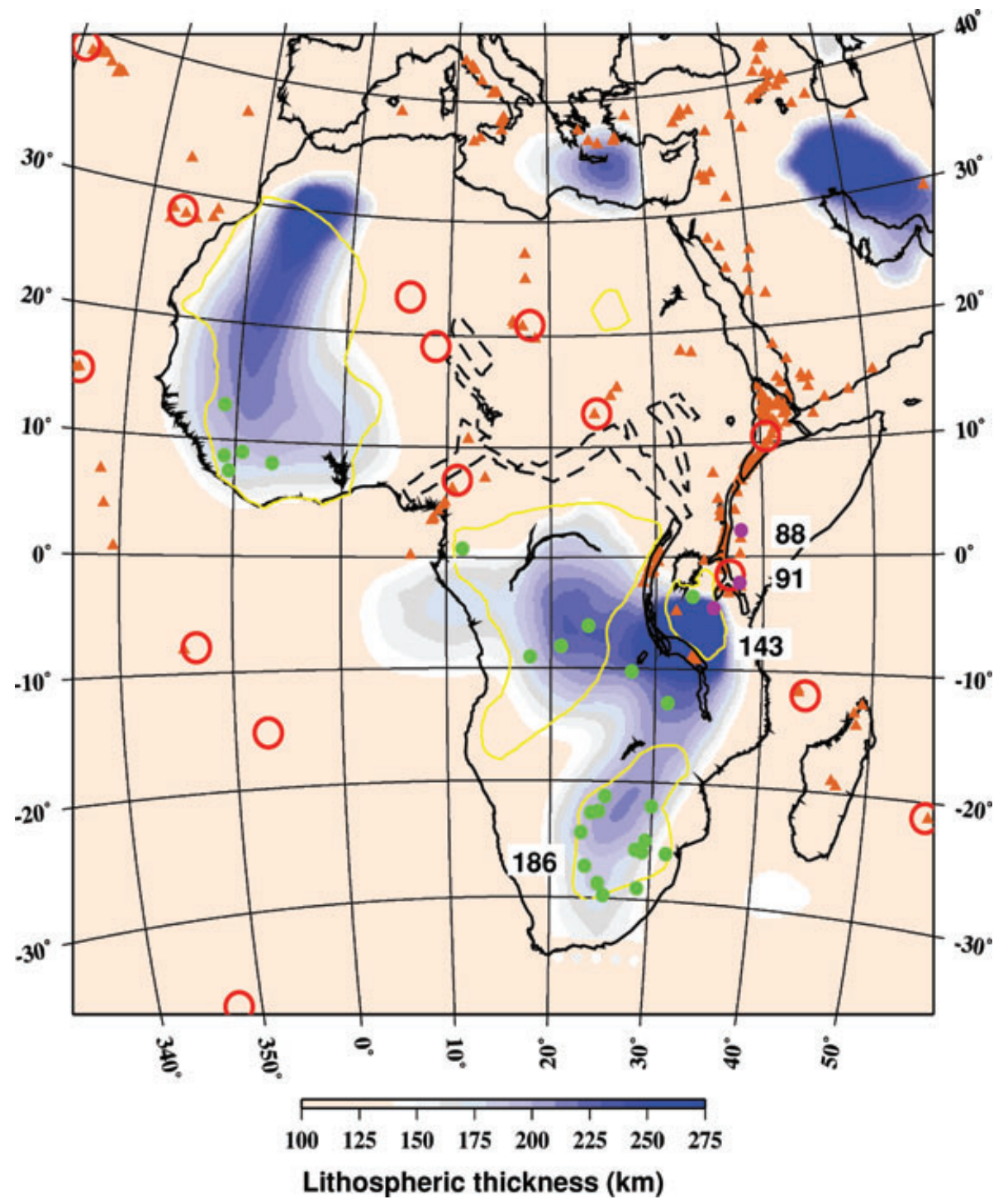

Figure 8. Contour map of lithospheric thickness beneath Africa calculated from the surface wave tomography using the relationship between seismic wave speed and temperature, of Priestley \& McKenzie (2006). Large red circles denote locations of postulated plumes, small red triangles locations of volcanoes, green circles locations of diamondiferous kimberlites (Nixon 1987; Janse \& Sheahan 1995) and purple circles locations of alkali basalts containing mantle nodules, whose mineral compositions have been used to estimate lithospheric thickness. The surface manifestation of the cratons is indicated by the yellow contours. Numbers in white boxes show the thickness of the lithosphere, estimated from the composition of minerals in mantle nodules.

Cratons and are encased within Pan-African age rocks that result from the assembly of Gondwanaland (Burke 1996). Large parts of the Congo and West African Cratons and the western part of the Kalahari Craton are covered by later sediments, and therefore, the spatial extent of these cratons is not well known (Kampunzu \& Popoff 1991; Key 1992). A great deal of geological and geophysical work has been published on the Kalahari Craton of southern Africa, but relatively little is known about the other cratons.

The West African Craton extends over most of western Africa, from south of the Atlas Mountains of Morocco and Algeria in the north to the Gulf of Guinea in the south. In the west, the West African Craton is bounded by the Mauretanide fold belts, and its eastern edge is covered by the Phanerozoic sediments of the Sahara. The oldest rocks occur in scattered masses that metamorphosed between 2.9 and $2.5 \mathrm{Ga}$. Archean basement is exposed in the western parts of both the Reguibat and Man shields in the north and south part of the craton, respectively, but the central part of the West African Craton is covered by the thick sediments of the Taoudeni Basin (Goodwin 1996). Available heat flow data for the West African Craton are scarce, but the one that does exist, shows the heat flow is low: $\sim 33 \pm 8 \mathrm{~mW} \mathrm{~m}^{-2}$ (Lesquer \& Vasseur 1992). A high-velocity upper-mantle lid underlies all of the West African Craton to a depth of $200-250 \mathrm{~km}$ (Fig. 4). Velocities are $\sim 5$ per cent fast with respect to the reference model at $100-150 \mathrm{~km}$ depth and decrease to $\sim 4$ per cent fast at $200 \mathrm{~km}$ depth.

In the north the Maghrebides belt, which is related to the Alpine orogeny, has been thrust over the north edge of the thick lithosphere of the West African Craton. Similar examples, where the location of young orogenic belts are controlled by the thick cratonic cores, have been observed in North America (Priestley \& McKenzie 2006) and Asia (Priestley et al. 2006a; Emmerson et al. 2006). The boundary with the Pan-African terrane to the northeast is sharp (profile A-A', Fig. 5), but in the southeast, the boundary appears diffused and bleeds into the NW portion of the Congo Craton (profile 
C-C', Fig. 5). However, it is likely that the more diffuse boundary in the southeast is due at least in part to lateral smearing between the high-velocity anomalies associated with the West African and Congo Cratons. The lithosphere is thickest in the northern part of the West African Craton (Fig. 8); diamondiferous kimberlites occur in the southern parts of the West African Craton.

The Congo Craton of central Africa is composed of Archean crust, exposed in a ring of Archean terranes of diverse size and separated from one another by intervening Proterozoic belts or cover surrounding the Congo Basin (Goodwin 1996). Most of these terranes have been stable since the end of the Archean. The limited data available suggest that the basement of the Congo Basin, which lies below as much as $4 \mathrm{~km}$ of Phanerozoic and Late Proterozoic sediment, appears to link with the Archean rocks exposed in the surrounding belts (Goodwin 1991). A 4-6 per cent high-velocity upper-mantle lid underlies the northwest part of the Congo Craton to a depth of about $200 \mathrm{~km}$, somewhat less than beneath the West African Craton.

An unexpected result of our Africa model is the high-velocity feature, extending from the Congo Craton westward into the Gulf of Guinea at 100-150 km depth (Fig. 4). A similar high-velocity anomaly appears in other Africa surface-wave tomography models (Ritsema \& van Heijst 2000; Sebai et al. 2006; Pasyanos \& Nyblade 2007). At $100 \mathrm{~km}$ depth, the high-velocity anomaly beneath the Gulf of Guinea could be attributed to the base of the old oceanic lithospheric plate, but the narrower feature in the $150-\mathrm{km}$-depth map is probably too deep to be related to the oceanic lithosphere. Some smearing does occur in this region in the checkerboard test, but as pointed out by Lévêque et al. (1993), checkerboard tests can be misleading because of the difference in geometry of the real and checkerboard structures. Fig. (A3) shows the effect of horizontal smearing from the tomography in a synthetic model in which the Congo Craton is represented by a circular plate. This shows that in this model, the high velocities of the plate representing the Congo Craton are smeared to the west. We therefore suspect that the highvelocity feature extending from the Congo Craton westward into the Gulf of Guinea (Fig. 4) results from poor path coverage in this region.

Pasyanos \& Nyblade (2007) find a thick upper-mantle lid beneath most of the Congo Craton but a thin, high-velocity lid beneath the Congo Basin within the craton. Our model has a thick, high-velocity lid beneath the whole Congo Craton, as does the upper-mantle models of Ritsema \& van Heijst (2000) and Sebai et al. (2006). Pasyanos \& Nyblade (2007) suggest that the high-velocity lid in models like ours results from the high velocities in the surrounding region bleeding inward in the tomographic inversion, to give the appearance of a high-velocity lid beneath the Congo Basin, but they do not substantiate this with resolution tests of their own model. We show results of several resolution tests in Fig. (A4). The Congo Basin is $\sim 10^{\circ}$ in diameter. We test the resolution in this part, of our model, by evaluating the recovery of a high-velocity annulus in the mantle beneath this part of Africa. Fig. (A4) shows that if the postulated region with a thin lid had a diameter of $750 \mathrm{~km}$ or more and was centred within a thick, high-velocity lid region, it would be detected by our data. If the diameter of the region with thin lid was $\sim 500 \mathrm{~km}$ in diameter, it would be weakly detected but would probably not be recognized. As a result of these tests, we agree with Ritsema \& van Heijst (2000) and Sebai et al. (2006) that a thick, high-velocity lid likely exists beneath the whole of the Congo Craton, including the Congo Basin, in contrast to the suggestion of Pasyanos \& Nyblade (2007). Why there is this difference in these models is unclear, but it may result from the fact that Pasyanos \& Nyblade (2007) invert higher-frequency Love and Rayleigh fundamental-mode group velocity data for the best isotropic structure. Anderson \& Dziewonski (1983) point out that an isotropic inversion of Rayleigh- and Lovewave dispersion data can lead to an artificial low-velocity layer at depths where the Love waves lose sensitivity.

High velocities ( $>3$ per cent) persist to a much greater depth beneath the Tanzanian Craton (Fig. 5c), and the northeastern boundary of the Tanzania Craton is extremely sharp (Figs 5 and 8). Independent estimates of the change in the lithospheric thickness across this boundary come from temperature and pressure estimates from upper-mantle nodules brought up in volcanic eruption. The values of lithospheric thickness determined from these nodules increase from 88 to $143 \mathrm{~km}$ (Fig. 8) in a distance of about $350 \mathrm{~km}$, where the lithospheric thickness calculated from $V_{S}$ also shows a rapid increase. Using $P$-wave delay time tomography, Ritsema et al. (1998) found that the high velocities extended to a depth of at least 200 $\mathrm{km}$ and possibly to $300-350 \mathrm{~km}$, forming a thick root to the Tanzania Craton. The high-velocity keel is surrounded by a 5-6 per cent lower velocity region, extending to $\sim 400 \mathrm{~km}$. On the other hand, using fundamental mode surface wave analysis, Weeraratne et al. (2003) observed that high $S$ velocities beneath the Tanzania Craton extended only to $150 \pm 20 \mathrm{~km}$, and beneath this, there is a substantial low velocity zone, reaching a minimum $4.20 \pm 0.05 \mathrm{~km} \mathrm{~s}^{-1}$ at $200-250 \mathrm{~km}$ depth. They suggest that the mantle beneath the Tanzanian Craton has been affected by an upwelling hot mantle plume. However, low heat flow is observed in the interior of Tanzania Craton, similar to that observed for other cratons (Nyblade 1997). Our synthetic tests (Fig. A2) show the depth resolution in this part of our model is about $\pm 10 \mathrm{~km}$ in the top $200 \mathrm{~km}$ and $\pm 25 \mathrm{~km}$ at deeper depths. The difference in depth sensitivity of the fundamental mode alone, compared with the fundamental mode plus higher modes may lead to significant differences in the resolved velocity structure in the deeper parts of the model and may be the explanation for these differences in models for the Tanzania Craton. This will require further investigation.

The Kalahari Craton (Fig 1) has formed a stable unit for the past 2.3 Gyr (McElhinny \& McWilliams 1977; Goodwin 1996). The upper-mantle seismic structure has been intensively analysed (e.g. Bloch et al. 1969; Cichowicz \& Green 1992; Qiu et al. 1996; Priestley 1999; Zhao et al. 1999; Freybourger et al. 2001; James et al. 2001; Saltzer 2002; Fouch et al. 2004; Larson et al. 2006; Li \& Burke 2006; Priestley et al. 2006b; Chevrot \& Zhao 2007), and a great deal of petrological and geochemical work has been carried out on the mantle nodules from the kimberlite pipes of southern Africa (e.g. Gurney \& Harte 1980; Boyd \& Mertzman 1987; Boyd et al. 1999; James et al. 2004). However, southern Africa has an anomalously high elevation, suggesting that the Kalahari Craton may not be representative of Archean cratons, in general. The structure beneath southern Africa in the model presented here is substantially the same as discussed in Priestley et al. (2006b). At $100-150 \mathrm{~km}$ depth in our model (Figs $4 \mathrm{a}$ and b), the $S V$-wave speed is $>4$ per cent high over much of southern Africa and is as much as 6 per cent high beneath the central Kalahari Craton. At $200 \mathrm{~km}$ depth, velocities are 1-2 per cent high over a restricted region (Fig. 4c), and by $250 \mathrm{~km}$ depth, the wave speed beneath southern Africa is similar to the wave speed at this depth beneath the surrounding oceans. Profile B-B' (Fig. 5) shows that the high-velocity lid beneath the Kalahari Craton is somewhat thinner than that found beneath the other African cratons.

Archean crust is exposed in the Uweinat inlier in northeastern Africa (Fig. 1), and Key (1992) and Schluter (2005) consider this Archean crust to be part of a larger Uweinat-Chad Craton. If the 
Uweinat-Chad Craton does exist, it does not appear to possess a thick, high-velocity or lithospheric root, similar to those observed beneath the cratons of western and southern Africa.

\subsection{The Pan-African Terrane}

The African Archean cratons are embedded in a matrix of arcsystem rocks that formed primarily between 0.9 and 0.5 Ga during the assembly of Gondwanaland. A great deal of arc-assembly, intracontinental rifting, ocean opening and closing and continental collision is recorded in this matrix (Burke 2009). Between 0.75 and $0.5 \mathrm{Ga}$, mountain building during the assembly of Gondwanalandthe Pan-African Orogeny - dominated the development of the matrix (Kennedy 1964, 1996), but the cratons remained relatively stable, cool and undeformed (Shackleton 1976). The Pan-African Orogeny coincided with the building of Africa and has been the dominant influence on the subsequent evolution of the continent.

The difference in mantle structure between the cratons and PanAfrican terranes of northern Africa is apparent in our upper-mantle shear wave model. Throughout northern Africa, the Pan-African is underlain by a warm, low-velocity upper mantle, and the lithosphere is too thin to be resolved with our surface wave analysis. Low wave speeds (as low as -4 per cent) extend to $250-300 \mathrm{~km}$ depth beneath the Hoggar-Air-Tibesti volcanic region in northcentral Africa, and more subdued low velocities occur at deeper depths beneath the Cameroon Line (Fig. 5). The Darfur volcanic centre occurs above the low wave speed upper mantle along the northern edge of the high-velocity mantle associated with the Congo Craton (Fig. 5). The Late Cretaceous rifts of North and Central Africa occur within the Pan-African terrane, above its subsurface boundary with the high-velocity mantle associated with the West African and Congo Cratons.

The low-velocity mantle of our Africa mantle model is consistent with earlier seismic observations for this region. Dorbath \& Montagner (1983) interpreted regionalized Rayleigh-wave group velocities as indicating a relatively thick upper-mantle high-velocity lid beneath the West African Craton and a thin or missing highvelocity lid beneath the Pan-African terrane to the east of the West African Craton. Ayadi et al. (2000) found $P$-wave velocities beneath the Hoggar, as much as 5 per cent low to $\sim 300 \mathrm{~km}$ depth. A teleseismic traveltime experiment in the vicinity of the Cameroon Line shows the presence of a low-velocity region, extending to a depth of $\sim 200 \mathrm{~km}$ (Dorbath et al. 1986), but the velocity contrasts are much weaker than for the Hoggar (Ayadi et al. 2000) and do not exceed 2.5 per cent.

The low wave speed Pan-African upper mantle of northern Africa coincides with widespread but minor volume volcanism. The volcanic centres of Hoggar (Lesquer et al. 1988; Dautria \& Lesquer 1989), Air (Black \& Girod 1970), Tibesti (Gourgaud \& Vincent 2004), Darfur (Franz et al. 1997, 1999) and Cameroon (Halliday et al. 1990; Deruelle et al. 1991) have been attributed to mantle plumes. The available heat flow observations show no significant regional thermal disturbance associated with the Hoggar, and xenoliths from recent basaltic eruptions suggest that the upper mantle beneath Hoggar is highly modified (Lesquer et al. 1988). Although the Tibesti volcanism may be related to a plume, there is little data to support this interpretation (Gourgaud \& Vincent 2004). Volcanics associated with the early stages of the Tibesti volcanism cover a broad region, extending $\sim 1000 \mathrm{~km}$ north, across Libya to the Mediterranean coast near Tripoli (Liegeois et al. 2005). Darfur volcanics are similar in nature to the volcanics of Tibesti, Hoggar and Air. The Cameroon Line extends for $\sim 500 \mathrm{~km}$ along the Pan-
African belt lying between the West African and Congo Cratons. The volcanic centres extend off-shore for $\sim 900 \mathrm{~km}$ into the Gulf of Guinea, and the common signature of the continental and oceanic volcanic products points to a similar sublithospheric source for the basalts (Marzoli et al. 2000).

The heat flow across northern Africa decreases from high (80$120 \mathrm{~mW} \mathrm{~m}^{-2}$ ) in the Sahara basins, north of the Hoggar in Algeria (Lesquer et al. 1990), to slightly elevated to normal $\left(\sim 80 \mathrm{~mW} \mathrm{~m}^{-2}\right)$ in the Sirt Basin of Libya (Nyblade et al. 1996), to normal or low $\left(35-70 \mathrm{~mW} \mathrm{~m}^{-2}\right)$ in eastern Egypt inland from the Red Sea (Nyblade et al. 1996), to high (75-100 $\mathrm{mW} \mathrm{m}^{-2}$ ) in eastern Egypt adjacent to the Red Sea (Morgan et al. 1985). However, Burke (2008, personal communications) questions the reliability of the Nyblade et al. (1996) results, because they are based on bottom-hole temperature measurements in oil wells. Considering the high heat flow, low upper-mantle shear velocities, low gravity and petrology for the Sahara basins in Algeria, Lesquer \& Vasseur (1992) argue that the upper mantle north of Hoggar is anomalously hot, but Nyblade et al. (1996) contend that if this is the case, it is not a condition extending across all of northern Africa.

At the surface, the Congo and Kalahari Cratons are separated by the Damara Province, a 400-km-wide Pan-African mobile belt (Fig 1). Whereas Pan-African rocks throughout the rest of Africa are underlain by a low wave speed upper mantle and lithosphere too thin to be resolved with the long-period surface wave analysis we employ, the Damara mobile belt in our model is underlain by a relatively thick, high-velocity upper-mantle lid (Fig. 4) and lithosphere (Fig. 8). Our synthetic tests show that in this part of our model, some horizontal smearing occurs between the high velocities beneath the Congo and Kalahari Cratons (Fig. A3) at $200 \mathrm{~km}$ depth, but the features are resolved at $150 \mathrm{~km}$ depth. The Damara Belt is the only Pan-African terrane of Africa, devoid of recent (>30 Ma) volcanism. The higher velocities we observe beneath the Damara Belt are consistent with the view of Burke (2009) that this Pan-African belt is a shallow feature above the suture of the Congo and Kalahari Cratons. Northern Africa was subjected to a great deal of strike-slip faulting and rifting associated with the Pan-African collapse ( $c a$. 520-380 Ma), and the prolonged thermal subsidence documented in the sedimentary basins indicates substantial lithospheric thinning (Burke et al. 2003; Burke 2009).

\subsection{Afar and the East African Rift}

The Afar region of eastern Africa is an area of uplift, volcanism and rifting associated with opening of the Red Sea, the Gulf of Aden and the East Africa Rift. Volcanism and uplift initiated in the present-day region of the Ethiopia-Yemen Plateau at $\sim 45$ Ma have continued to the present (Ebinger et al. 1993; Burke 1996), with the bulk of the volcanism at $\sim 30$ Ma thought to mark the appearance of the Afar plume at the surface and the onset of the main phase of rifting (Hofmann et al. 1997). Ebinger \& Sleep (1998) suggest that many, if not all, of the volcanic centres in North and Central Africa (Darfur, Tibesti, Cameroon) are related to the Afar plume, with plume material flowing laterally beneath the lithosphere and feeding these volcanic centres.

Very low velocities occur in the region of Afar and the triple junction at the south end of the Red Sea. Velocities 2-3 per cent low, compared with the reference, extend to at least $350 \mathrm{~km}$ depth beneath Afar. At 100-150 km depth, they are 4-7 per cent low and a band of low velocity extends along the length of the Red Sea and the adjacent regions of Africa and Arabia and northwards into Jordan and Syria. 
Debayle et al. (2001) use the same analysis procedures we employ here, but they used a smaller surface-wave data set to image the Afar region and found low velocities similar to those we see extending to at least $400 \mathrm{~km}$ depth. Resolution tests showed that their data and analysis were capable of resolving deep, low wave speed structure to transition zone depths beneath the Afar region. Since the data set in our study is a significant expansion of the Debayle et al. (2001) data set, the resolution in the Afar region of our model should be similar to or better than that demonstrated by Debayle et al. (2001). Their work and the body-wave tomography study of Benoit et al. (2006) suggest that the thermal anomaly beneath the Afar extends at least to transition zone depths.

\section{SUMMARY AND CONCLUSIONS}

This paper focuses on the upper-mantle velocity structure of the African continent and its relationship to the surface geology. We use a substantial multimode Rayleigh-wave data set to image the $S V$-wave speed structure, with a horizontal resolution of several hundred kilometres and a vertical resolution of $\sim 50 \mathrm{~km}$, to a depth of about $400 \mathrm{~km}$. We have used the relationship between $V_{S}$-wave speed and temperature by Priestley \& McKenzie (2006) to estimate temperatures in the African upper mantle and the variation in temperature gradient to determine the depth to the base of the lithosphere beneath the cratons.

High-velocity (4-7 per cent) roots are observed beneath the cratons. Below the West African, Congo and Tanzanian Cratons these extend to $225-250 \mathrm{~km}$ depth, but beneath the Kalahari Craton, the high wave speed root extends to only $\sim 170 \mathrm{~km}$. In general, the PanAfrican terrane of Africa is underlain by low wave speed mantle. If any high velocity upper-mantle lid exists beneath the Pan-African terrane of northcentral Africa, it is too thin for us to measure with our current surface-wave analysis technique. The Pan-African Damara Belt, separating the Congo and Kalahari Cratons is the exception because it is underlain by higher wave speed upper mantle than are the Pan-African terranes of northcentral Africa. Extremely low $S V$-wave speeds occur to the bottom of our model, beneath the Afar region.

The upper mantle beneath the African cratons is cool to 175$200 \mathrm{~km}$ depth. Thick lithosphere exists beneath all of the cratonic areas. Independent evidence for this thick lithosphere comes from the petrology of upper-mantle nodules, brought up in some volcanic eruptions and in the locations of diamondiferous kimberlites. Almost all diamond locations occur where the lithosphere is 175-200 km thick but are largely absent from the regions of the thickest lithosphere. With the exception of the Damara Belt in southern Africa, temperatures beneath the Pan-African terrane are similar to those at the same depths in the upper mantle beneath the surrounding ocean. Somewhat higher temperatures occur beneath the Afar-Red Sea region. The lithosphere beneath the Pan-African terrane of northcentral Africa is too thin to resolve.

Much of this region of northcentral and eastern Africa has experienced volcanism in the past $\sim 30 \mathrm{Ga}$. It is interesting to note that the Pan-African Damara Belt is the only Pan-African terrane in Africa, devoid of recent volcanism. Both the mantle wave speed structure and the lack of recent volcanism are consistent with the view of Burke (2009) that the Damara Belt is different from the other Pan-African terranes of Africa and is a shallow feature above the suture of the Congo and Kalahari Cratons.

Our model of the upper mantle beneath Africa is largely consistent with the views of Ashwal \& Burke (1989), who contend that two kinds of upper mantle underlie Africa, undepleted upper mantle beneath the cratons and fertile upper mantle beneath the Pan-African terranes.

\section{ACKNOWLEDGMENTS}

This study would not have been possible without permanent and temporary seismographs operated in Africa and the surrounding region. Our study has included data from the ASRO/SRO, GEOFON, GEOSCOPE, IRIS-IDA and IRIS-USGS permanent seismic networks and the Tanzania BB Experiment, SASEK, eastern Turkey Seismic Experiment and Saudi Arabia Broadband Array PASSCAL and the Horn of Africa INSU temporary seismic deployments. This research has benefited from discussions with K. Burke, M. Cara and J.-J. Leveque. KP would like to thank the Institut de Physique $\mathrm{du}$ Globe de Strasbourg for supporting time in which to pursue this work. ED was supported by programme DyETI conducted by the French Institut National des Sciences de l'Univers (INSU) and ANR TOMOGLOB no ANR-06-JCJC-0060. We thank Jamie Barron for computer coding support. A number of the figures were prepared using the Generic Mapping Tool (Wessel \& Smith 1995). This is Cambridge University Department of Earth Sciences contribution ES9307.

\section{REFERENCES}

Anderson, D. \& Dziewonski, A., 1983. Upper mantle anisotropy: evidence from free oscillations, Geophys. J. R. astr. Soc., 69, 383-404.

Ashwal, L. \& Burke, K., 1989. African lithospheric structure, volcanism, and topography, Earth planet. Sci. Lett., 96, 8-14.

Ayadi, A., Dorbath, C., Lesquer, A. \& Bezzeghoud, M., 2000. Crustal and upper mantle velocity structure of the Hoggar swell (Central Sahara, Algeria), Phys. Earth planet. Inter., 118, 111-123.

Benoit, M., Nyblade, A., Owens, T. \& Stuart, G., 2006. Mantle transition zone structure and upper mantle $\mathrm{S}$ velocity variations beneath Ethiopia: evidence for a broad, deep-seated thermal anomaly, Geochem. Geophys. Geosys., 7, doi:10.1029/2006GC001398.

Beucler, E., Stutzmann, E. \& Montagner, J.-P., 2003. Surface-wave higher mode phase velocity measurements, using a roller-coaster type algorithm, Geophys. J. Int., 155, 289-307.

Black, R. \& Girod, M., 1970. Late Palaeozoic to Recent igneous activity in West Africa and its relationship to basement structures, in Africa Magmatism and Tectonics, pp. 185-210, eds Clifford, T. \& Gass, I., Oliver and Boyd, Edinburgh.

Bloch, S., Hales, A. \& Landisman, M., 1969. Velocities in the crust and upper mantle of southern Africa from multi-mode surface wave dispersion, $B$. seism. Soc. Am., 59, 1599-1629.

Bond, G., 1979. Evidence for some uplifts of large magnitude in continental platforms, Tectonophysics, 61, 285-305.

Boyd, F. \& Mertzman, S., 1987. Composition and structure of the Kaapvaal lithosphere, southern Africa, in Magmatic Processes: Physicochemical Principles, pp. 13-24, ed. Mysen, B., Geochem. Soc., University of Pennsylvania, University Park, PA.

Boyd, F., Pearson, D. \& Mertzman, S., 1999. Spinel-facies peridotites from the Kaapvaal Root, in Proceedings of the 7th International Kimberlite Conference, The J.B. Dawson Volume, pp. 40-49, ed. Gurney, J., Red Roof Design, Cape Town, S. Afr.

Burke, K., 1996. The African Plate, S. Afr. J. Geol., 99, 339-410.

Burke, K., 2009. The PanAfrican orogeny, unpublished book chapter.

Burke, K. \& Wilson, J.T., 1972. Is the African Plate stationary?, Nature, 239, 387-390.

Burke, K., MacGregor, D. \& Cameron, N., 2003. Africa's petroleum systems: four tectonic aces in the past 600 million years, in Petroleum Geology of Africa: New Themes and Developing Technologies, vOL. 207, eds Arthur, 
T., MacGregor, D. \& Cameron, N., Geol. Soc. Spec. Publ., London, p. 2160.

Cahen, L., Snelling, N., Delhal, J. \& Vail, J., 1984. The Geochronology and Evolution of Africa, Oxford University Press, New York.

Cara, M. \& Lévêque, J., 1987. Waveform inversion using secondary observables, Geophy. Res. Lett., 14, 1046-1049.

Chevrot, S. \& Zhao, L., 2007. Multiscale finite-frequency Rayleigh wave tomography of the Kaapvaal craton, Geophys. J. Int., 169, 201-215, doi:10.1111/j.1365-246X.2006.03289.x.

Cichowicz, A. \& Green, R., 1992. Tomographic study of the upper-mantle structure of the South African continent, using wave-form inversion, Phys. Earth planet. Inter., 72, 276-285.

Dautria, J. \& Lesquer, A., 1989. An example of the relationship between rift and dome: recent geodynamic evolution of the Hoggar swell and of its nearby regions (Central Sahara, Southern Algeria and Eastern Niger), Tectonophysics, 163, 45-61.

Debayle, E., 1999. $S V$-wave azimuthal anisotropy in the Australian upper mantle: preliminary results from automated Rayleigh waveform inversion, Geophys. J. Int., 137, 747-754.

Debayle, E. \& Kennett, B., 2000a. The Australian continental upper mantle: structure and deformation inferred from surface waves, J. geophys. Res., 105, 25 423-25 450.

Debayle, E. \& Kennett, B., 2000b. Anisotropy in the Australasian upper mantle from Love and Rayleigh waveform inversion, Earth planet. Sci. Lett., 184, 339-351.

Debayle, E. \& Sambridge, M., 2004. Inversion of massive surface wave data sets: model construction and resolution assessment, J. geophys. Res., 109, doi:10.1029/2003JB002652.

Debayle, E., Lévêque, J.-J. \& Cara, M., 2001. Seismic evidence for a plume in the upper mantle beneath the northeastern Afro/Arabian continent, Earth planet. Sci. Lett., 193, 423-436.

Debayle, E., Kennett, B. \& Priestley, K., 2005. Global azimuthal seismic anisotropy and the unique plate-motion deformation of Australia, Nature, 433, 509-512.

Deruelle, B., Moreau, C., Nkoumbou, C., Kambou, R., Lissom, J., Njonfang, E., Ghogomu, R. \& Nono, A., 1991. The Cameroon Line: a review, in Magmatism in Extensional Structural Settings, The Phanerozoic African Plate, pp. 274-327, eds Kampunzu, A. \& Lubala, R., Springer, Berlin.

Dorbath, L. \& Montagner, J.-P., 1983. Upper mantle heterogeneities in Africa deduced from Rayleigh wave dispersion, Phys. Earth planet. Inter., 32, 218-225.

Dorbath, C., Dorbath, L., Fairhead, J. \& Stuart, G., 1986. A teleseismic delay time study across the Central African Shear Zone in the Adamawa region of Cameroon, Geophys. J. R. astr. Soc., 86, 751-766.

Doucoure, C. \& deWit, M., 2003. Old inherited origin for the present nearbimodal topography of Africa, J. Afr. Earth. Sci., 36, 371-388.

Dziewonski, A, M. \& Anderson, D., 1981. Preliminary reference earth model, Phys. Earth planet. Inter., 25, 297-356.

Ebinger, C. \& Sleep, N., 1998. Cenozoic magmatism throughout east Africa resulting from the impact of a single plume, Nature, 395, 788-791.

Ebinger, C., Yemana, T., WoldeGagriel, G., Aronson, i.J. \& Walter, R., 1993. Late Eocene-Recent volcanism and rifting in the southern main Ethiopian rift, J. Geol. Soc. Lond., 150, 99-108.

Emmerson, B., Jackson, J., McKenzie, D. \& Priestley, K., 2006. Seismicity, structure and rheology of the lithosphere in the Lake Baikal region, Geophys. J. Int., 167, 1233-1272.

England, P. \& Houseman, G., 1984. On the geodynamic setting of kimberlite genesis, Earth planet. Sci. Lett., 67, 109-122.

Fouch, M., D.E., J., VanDecar, J., van der Lee, S. \& the Kaapvaal Seismic Group, 2004. Mantle seismic structure beneath the Kaapvaal and Zimbabwe Cratons, S. Afr. J. Geol., 107, 33-44.

Franz, G., Breitkreuz, C., Coyle, D., El Hur, B., Heinrich, W., Paulick, H. D. P., Steiner, G. \& Smith, R., 1997. Geology of the alkaline Meidob volcanic field, Late Cenozoic, in Sudan, J. Afr. Earth. Sci., 253, 1-29.

Franz, G., Steiner, G., Volker, F. D. P. \& Hammerschmidt, 1999. Plume related alkaline magmatism in central Africa- - the Meidob Hills (W Sudan), Chem. Geol., 1573, 27-47.
Freybourger, M., Gaherty, J., Jordan, T. \& the Kaapvaal seismic group, 2001. Structure of the Kaapvaal Craton from surface waves, Geophy. Res. Lett., 28, 2489-2492.

Goodwin, A., 1991. Precambrian Geology, Academic Press, San Diego, CA, 666pp.

Goodwin, A., 1996. Princples of Precambrian Geology, Academic Press, San Diego, CA, 327pp.

Gourgaud, A. \& Vincent, P., 2004. Petrology of two continental alkaline intraplate series at Emi Koussi volcano, Tibesti, Chad, J. Volcanol. Geotherm. Res., 129, 261-290, doi:10.1016/S0377-0273(03)00277-4.

Gu, Y., Dziewonski, A. \& Ekstrom, G., 2001. Preferential detection of the Lehmann discontinuity beneath continents, Geophy. Res. Lett., 28, 46554658.

Guiraud, R. \& Maurin, J.-C., 1992. Early Cretaceous rifts of western and central Africa: an overview, Tectonophysics, 213, 153-168.

Gurney, J. \& Harte, B., 1980. Chemical variations in upper mantle nodules from southern Arican kimberlites, Phil. Tans. Roy. Soc., A, 297, 273-293.

Hadiouche, O. \& Jobett, N., 1988. Geographical distribution of surface-wave velocities and 3-D upper-mantle structure in Africa, Geophys. J. Int., 95, 87-109.

Halliday, A., Davidson, J., Holden, P., De Wolf, C., Der-Chuen, L. \& Fitton, J., 1990. Trace element-fractionation in plumes and the origin of HIMU mantle beneath the Cameroon Line, Nature, 347, 523-528.

Hartley, R., Watts, A. \& Fairhead, J., 1996. Isostasy of Africa, Earth planet. Sc. Lett., 137, 1-18.

Hofmann, C., Courtiollot, V., Feraud, G., Rochette, P., Yirgus, G., Ketefo, E. \& Pik, R., 1997. Timing of the Ethiopian flood basalt event and implications for plume birth and global change, Nature, 389, 838-841.

Holmes, A., 1944. Princples of Geology, Nelson, London, 532pp.

James, D., Boyd, F., Schutt, D., Bell, D. \& Carlson, R., 2004. Xenolith constraints in seismic velocities in the upper mantle beneath southern Africa, Geochem. Geophys. Geosys., 5, doi:10.1029/2003GC000551.

James, D., Fouch, M., VanDecar, J., van der Lee, S. \& the Kaapvaal Seismic Group, 2001. Tectospheric structure beneath southern Africa, Geophy. Res. Lett., 28, 2485-2488.

Janse, A. \& Sheahan, P., 1995. Catalogue of worldwide diamond and kimberlite occurrences: a selective and annotated approach, J. Geochem. Exp., 53, 73-111.

Jordan, T., 1979. Mineralogies, densities and seismic velocities of garnet lherzolite and their geophysical implications, in The Mantle Sample: Inclusions in Kimberlites and Other Volcanics, Proceedings 2nd International Kimberlite Conference, Vol. 2, pp. 155-165, eds Boyd, F. \& Meyer, H., AGU, Washington, D. C., .

Kampunzu, A. \& Popoff, M., 1991. Distribution of the main African Rifts and associated magmatism: introductory notes, in Magmatism in Extensional Structural Settings, the Phanerozoic African Plate, pp. 2-10, eds Kampunzu, A. \& Lubala, R., Springer-Verlag, Berlin, Heidelberg, New York, Tokoyo, Hong Kong, Barcelona, Budapest.

Kennedy, W., 1964. The structural differentiation of Africa in the Pan-Arican ( \pm 500 m.y.) tectonic episode, in 8th ann. Rep. Sci. Res. Inst. Afr. Geol., pp. 48-49, University of Leeds (Sess. 1962-63).

Kennedy, W., 1996. The influence of basement structure on the evolution of the coastal (Mesozoic and Tertiary) basins, in Salt Basins Around Africa, pp. 7-16, ed. Ion, D., The Institute of Petroleum, London.

Kennedy, C. \& Kennedy, G., 1976. The equilibrium boundary between graphite and diamond, J. geophys. Res., 81, 2467-2470.

Kennett, B., 1995. Approximations for surface-wave propagation in laterally varying media, Geophys. J. Int., 122, 470-478.

Kennett, B., Engdahl, E. \& Bulland, R., 1995. Constraints on seismic velocities in the Earth from traveltimes, Geophys. J. Int., 122, 108-124.

Key, R., 1992. An introduction to the crystalline basement of Africa, in Hydrogeology of Crystalline Basement Aquifers in Africa, Vol. 66, pp. 29-57, eds Wright, E. \& Burgess, W., Geol. Soc. Spec. Publ., London.

Larson, A., Snoke, J. \& James, D., 2006. $S$-wave velocity structure, mantle xenoliths and the upper mantle beneath the Kaapvaal Craton, Geophys. J. Int., pp. 1-16, doi:10.1111/j.1365-246X.2006.03005.x.

Lesquer, A. \& Vasseur, G., 1992. Heat-flow constrains on the West African lithosphere structure, Geophy. Res. Lett., 19, 561-564. 
Lesquer, A., Bourmatte, A. \& Dautria, J., 1988. Deep structure of the Hoggar domal uplift (Central Sahara, souther Algeria) from gravity, thermal and petrological data, Tectonophysics, 152, 71-87.

Lesquer, A., Takherist, D., Dautria, J. \& Hadiouche, O., 1990. Geophysical, and petrological evidence for an 'anomalous' upper mantle beneath the Sahara basin (Algeria), Earth planet. Sci. Lett., 96, 407418.

Lévêque, J.-J., Rivera, L. \& Wittlinger, G., 1993. On the use of the checkerboard test to assess the resolution of tomographic inersions, Geophys. $J$. Int., 115, 313-318.

Li, A. \& Burke, K., 2006. Upper mantle structure of southern Africa from Rayleigh wave tomography, J. Geophys. Res., 111, doi:1029/2006JB004321.

Liegeois, J.-P., Benhallo, A., Azzouni-Sekkal, A., Yahiaoui, R. \& Bonin, B., 2005, The Hoggar swell and volcanism: reactivation of the Precambrian Tuareg shied during Alpine convergence and West African Cenozoic volcanism, in Plates, Plumes, and Paradims, Vol. 388, pp. 379-400, eds Foulger, G., Natland, J., Presnall, D. \& Anderson, D., Geol. Soc. Am. Sp. Pap.

Maggi, A. \& Priestley, K., 2005. Surface waveform tomography of the Turkish-Iranian Plateau, Geophys. J. Int., 160, 1068-1080.

Maggi, A., Debayle, E., Priestley, K. \& Barruol, G., 2006. Multimode surface waveform tomography of the Pacific Ocean: a closer look at the lithospheric cooling signature, Geophys. J. Int., 166, 1384-1397, doi:10.1111/j.1365-24X.2006.03037.x.

Marquering, H., Snieder, R. \& Nolet, G., 1996. Waveform inversion and the significance of surface-wave mode coupling, Geophys. J. Int., 124, $258-278$.

McElhinny, M. \& McWilliams, M., 1977. Precambrian geodynamics: a paleomagnetic view, Tectonophysics, 40, 137-159.

McKenzie, D. \& Weiss, N., 1975. Speculations on the Thermal and Tectonic History of the Earth, Geophys. J. R. astr. Soc., 42, 131-174.

McKenzie, D., Jackson, J. \& Priestley, K., 2005. Thermal structure of oceanic and continental lithosphere, Earth planet. Sci. Lett., 233, 337-349.

Marzoli, A., Piccirillo, E., Renne, P., Bellieni, G., Iacumin, M., J.B., N. \& A.T., T., 2000. The Cameroon Volcanic Line revisited: petrogenesis of continental basaltic magmas from lithospheric and asthenospheric mantle sources, J. Petrol., 41, 87-109.

Mitra, S., Priestley, K., Bhattacharyya, A. \& Gaur, V., 2005. Crustal structure and earthquake focal depths beneath northeastern India and southern Tibet, Geophys. J. Int., 160, 227-248.

Montagner, J., 1986. Regional three-dimensional structures using longperiod surface waves, Ann. Geophys., 4, 283-294.

Mooney, W., Laske, G. \& Masters, G., 1998. Crust 5.1: a global crustal model at $5 \times 5$ degrees, J. geophys. Res., 103, 727-747.

Morgan, P., Boulos, F., Hennin, S., El-Sherif, A., El-Sayed, A., Basta, N. \& Melek, Y., 1985. Heat flow in eastern Egypt: the thermal signature of a continental breakup, J. Geodyn., 4, 107-131.

Nataf, H.-C. \& Ricard, Y., 1996. 3SMAC: an a priori tomographic model of the upper mantle based on geophysical modeling, Phys. Earth planet. Inter, 95, 101-122.

Nishimura, C. \& Forsyth, D., 1989. The anisotropic structure of the upper mantle in the Pacific, Geophys. J. Int., 96, 203-229.

Nixon, P., 1987. Mantle Xenoliths, John Wiley \& Son, New York.

Nyblade, A., 1997. Heat flow across the East Africa plateau, Geophy. Res. Lett., 24, 2083-2086.

Nyblade, A. \& Robinson, S., 1994. The African superwell, Geophy. Res. Lett., 21, 765-768.

Nyblade, A., Suleiman, I., Roy, R., Pursell, B., Suleiman, A., Doser, D. \& Keller, G., 1996. Terrestial heat flow in the Sirt Basin, Libya, and the pattern of heat flow across northern Africa, J. geophys. Res., 101, $17737-17746$.

Pasyanos, M. \& Nyblade, A., 2007. A top to bottom lithospheric study of Africa and Arabia, Tectonophysics, 444, 27-44.
Pilidou, S., Priestley, K., Gudmundsson, G. \& Debayle, E., 2004. Upper mantle S-wavespeed heterogeneity beneath the North Atlantic from regional surface waveform tomography: high resolution image of the Iceland plume, Geophys. J. Int., 159, 1057-1076.

Priestley, K., 1999. Velocity structure of the continental upper mantle: evidence from southern Africa, Lithos, 48, 45-56.

Priestley, K. \& McKenzie, D., 2006. The thermal structure of the lithosphere from shear wave velocities, Earth planet. Sci. Lett., 244, 285-301.

Priestley, K., Debayle, E., McKenzie, D. \& Pilidou, S., 2006a. Upper mantle structure of eastern asia from multi-mode surface waveform tomography, J. geophys. Res., doi:10.1029/2005JB004082.

Priestley, K., McKenzie, D. \& Debayle, 2006b. The state of the upper mantle beneath southern Africa, Tectonophysics, 416, 101-112.

Qiu, X., Priestley, K. \& McKenzie, D., 1996. Average lithospheric structure of southern Africa, Geophys. J. Int., 127, 563-587.

Ritsema, J. \& van Heijst, H., 2000. New seismic model of the upper mantle beneath Africa, Geology, 28, 63-66.

Ritsema, J., Nyblade, A., Owens, T., Langston, C. \& J.C., V., 1998. Upper mantle seismic velocity structure beneath Tanzania, east Africa: implications for the stability of cratonic lithosphere, J. geophys. Res., 102, $21201-21213$.

Ritzwoller, M. \& Levshin, A., 1998. Eurasian surface wave tomography: group velocities, J. geophys. Res., 103, 4839-4878.

Ritzwoller, M., Shapiro, N., Barmin, M. \& Levshin, A., 2002. Global surface wave diffraction tomography, J. geophys. Res., 107, 10.1029/2002JB001777.

Rodi, W., Glover, P., Li, T. \& Alexander, S., 1975. A fast, accurate method for computing group-velocity partial derivatives for Rayleigh and Love modes, Bull. Seism. Soc. Am., 65, 1105-1114.

Saltzer, R., 2002. Upper mantle structure of the Kaapvaal Craton from surface wave analysis: a second look, Geophy. Res. Lett., 29, doi:10.1029/2001GL013702.

Schluter, T., 2005. Geological Atlas of Africa, Springer-Verlag, New York.

Schutt, D. \& Lesher, C., 2006. Effects of melt depletion on the density and seismic velocity of garnet and spenel lherzolite, J. geophys. Res., 4111, doi: 10.1029/2003JB002950.

Sebai, A., Stutzmann, E., Montagner, J.-P., Sicilia, D. \& Beucler, E., 2006. Anisotropic structure of the African upper mantle from Rayleigh and Love wave tomography, Phys. Earth planet. Inter, 155, 48-62.

Shackleton, R., 1976. Pan-African structures, Phil. Tans. Roy. Soc., A, 280, 491-497.

Sieminski, A., Lévêque, J. \& Debayle, E., 2004. Can finite-frequency effects be accounted for in ray theory surface wave tomography?, Geophys. Res. Lett., 31, doi:10.1029/2004GL021402.

Swenson, J., Beck, S. \& Zandt, G., 2000. Crustal structure of the Altiplano from broadband regional waveform modeling: implications for the composition of thick continental crust, J. geophys. Res., 105, 607-622.

Thorpe, R. \& Smith, K., 1974. Distribution of Cenozoic volcanism in Africa, Earth planet. Sci. Lett., 22, 91-95.

Van Heijst, H. \& Woodhouse, J., 1999. Global high-resolution phase velocity distributions of overtone and fundamental-mode surface waves determined by mode branch stripping, Geophys. J. Int., 137, 601-620.

Weeraratne, D., Donald, W., Fisher, K. \& Nyblade, A., 2003. Evidence for an upper mantle plume beneath the Tanzanian craton from Rayleigh wave tomography, J. geophys. Res., 108, 2427-2446.

Wessel, P. \& Smith, W., 1995. New version of the generic mapping tool release, EOS, Trans. Am. geophys. Un., 76, 329.

Woodhouse, J., 1974. Surface waves in a laterally varying layered structure, Geophys. J. R. astr. Soc., 37, 461-490.

Yoshizawa, K. \& Kennett, B., 2002. Determination of the influence zone for surface wave paths, Geophys. J. Int., 149, 440-453.

Zhao, M., Langston, C., Nyblade, A. \& Owens, T., 1999. Upper mantle velocity structure beneath southern Africa from modeling regional seismic data, J. geophys. Res., 104, 4783-4794. 


\section{APPENDIX A: RESOLUTION TESTS}

We carry out a number of synthetic tests to assess the resolution of our $S_{\mathrm{V}}$-wave model for Africa. We use a checkerboard test to assess how well the 3-D tomographic images reflect the shapes and amplitudes of a given distribution of shear velocity heterogeneity. For this test, we create an input model consisting of $10^{\circ} \times 10^{\circ}$ $\times 100 \mathrm{~km}$ thick blocks having a \pm 6 per cent alternating wavespeed variation, superimposed on the reference model. The depth transition between the first and second layer of blocks is at 175

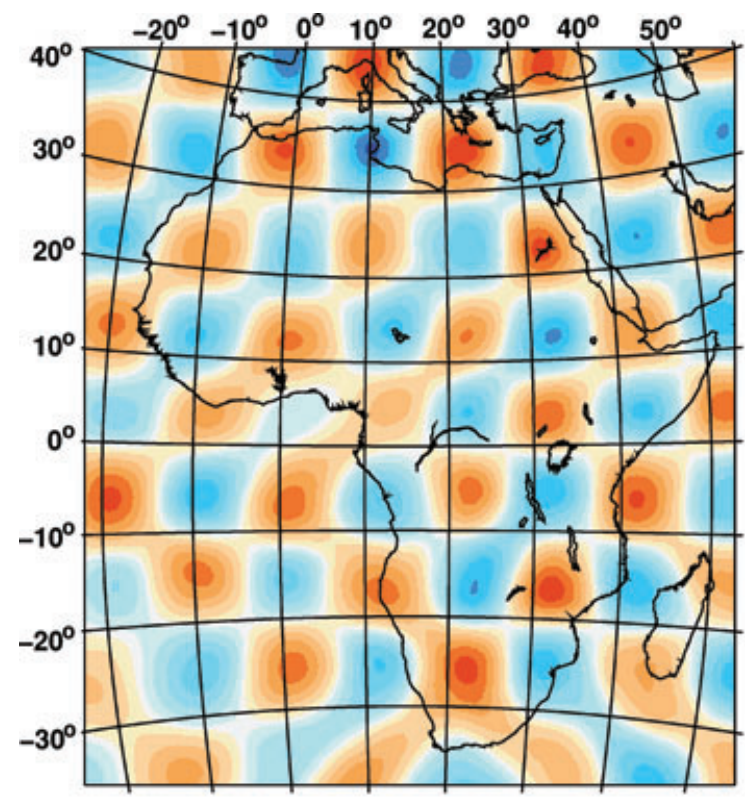

$\delta V s \% 100 \mathrm{~km}(\mathrm{Vsref}=\mathrm{km} / \mathrm{s})$
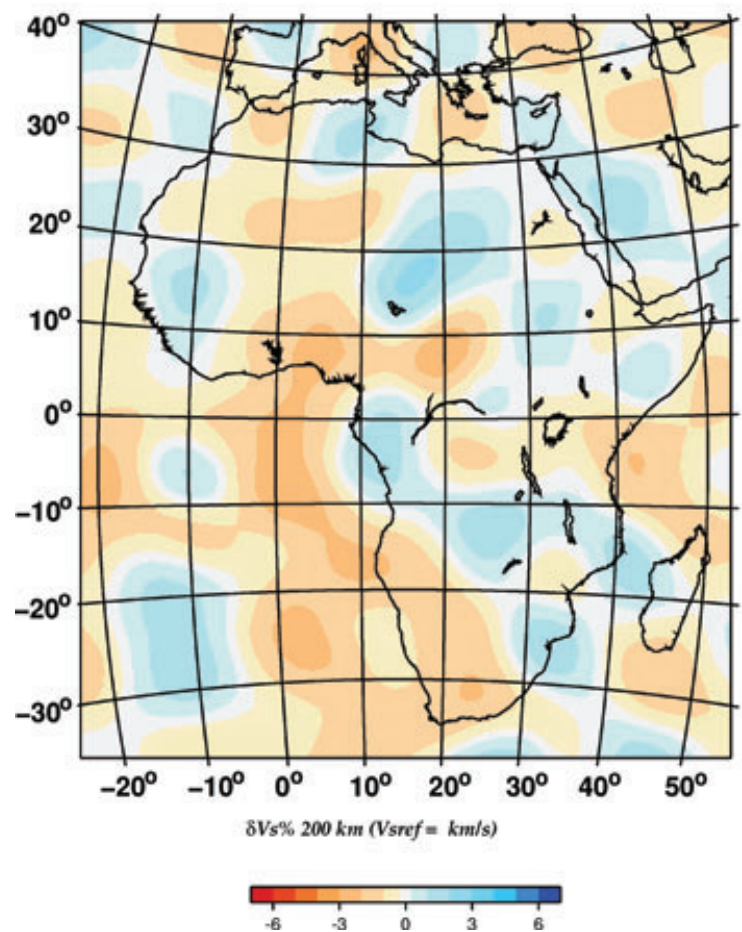

$\mathrm{km}$, between the second and third layers is at $275 \mathrm{~km}$ and between the third and fourth layers is at $375 \mathrm{~km}$. We assume a great circle path, then calculate the average velocity structure with depth along this path. We then use this structure to calculate the seismograms, assuming that the structure is 1-D. We calculate synthetic multimode seismograms for the same source parameters, frequency content, modal distribution and event-receiver combinations, as measured for the real surface wave data. The synthetic seismograms are then inverted in exactly the same way as the real data. By starting with the initial step of the 1-D waveform inversions, this test not only

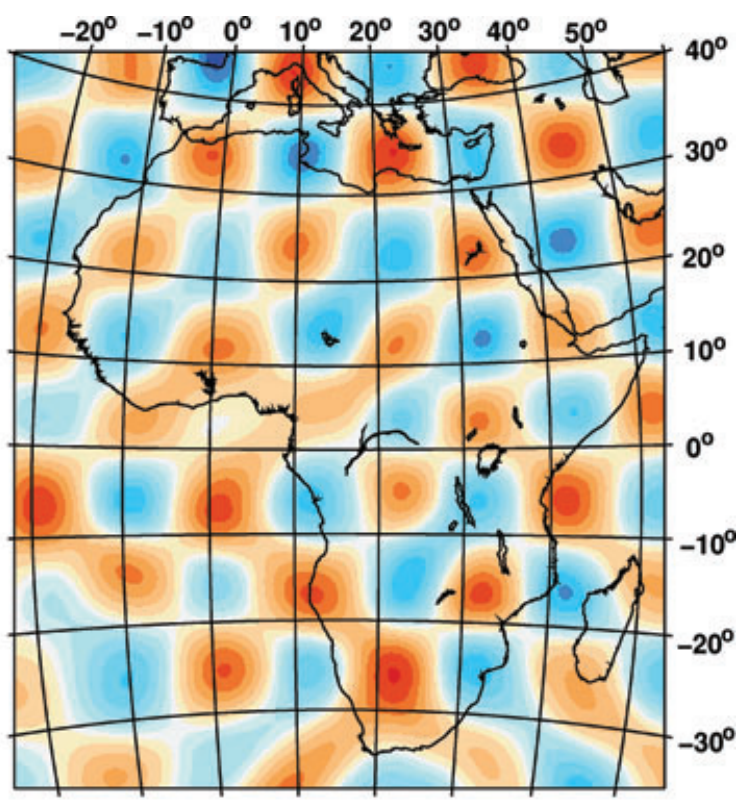

$8 \mathrm{Vs} \% 150 \mathrm{~km}(\mathrm{Vsref}=\mathrm{km} / \mathrm{s})$

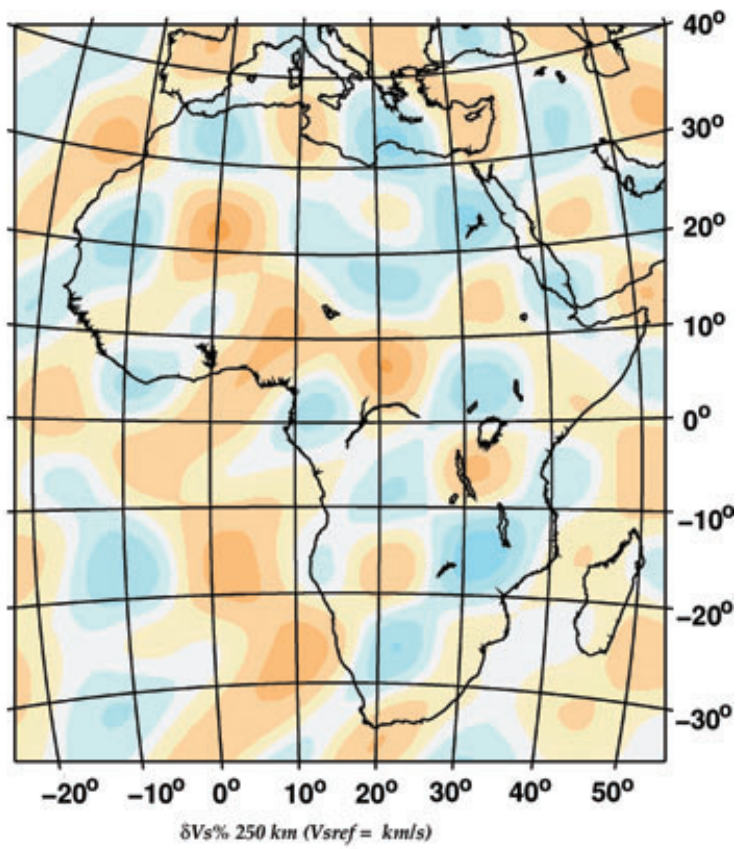

Figure A1. Checkerboard recovery test at four depths in the Africa model. The input consists of $10^{\circ} \times 10^{\circ} \times 100 \mathrm{~km}$ thick blocks having a \pm 6 per cent alternating wave-speed variation, superimposed on the reference model shown in Fig. 3. 

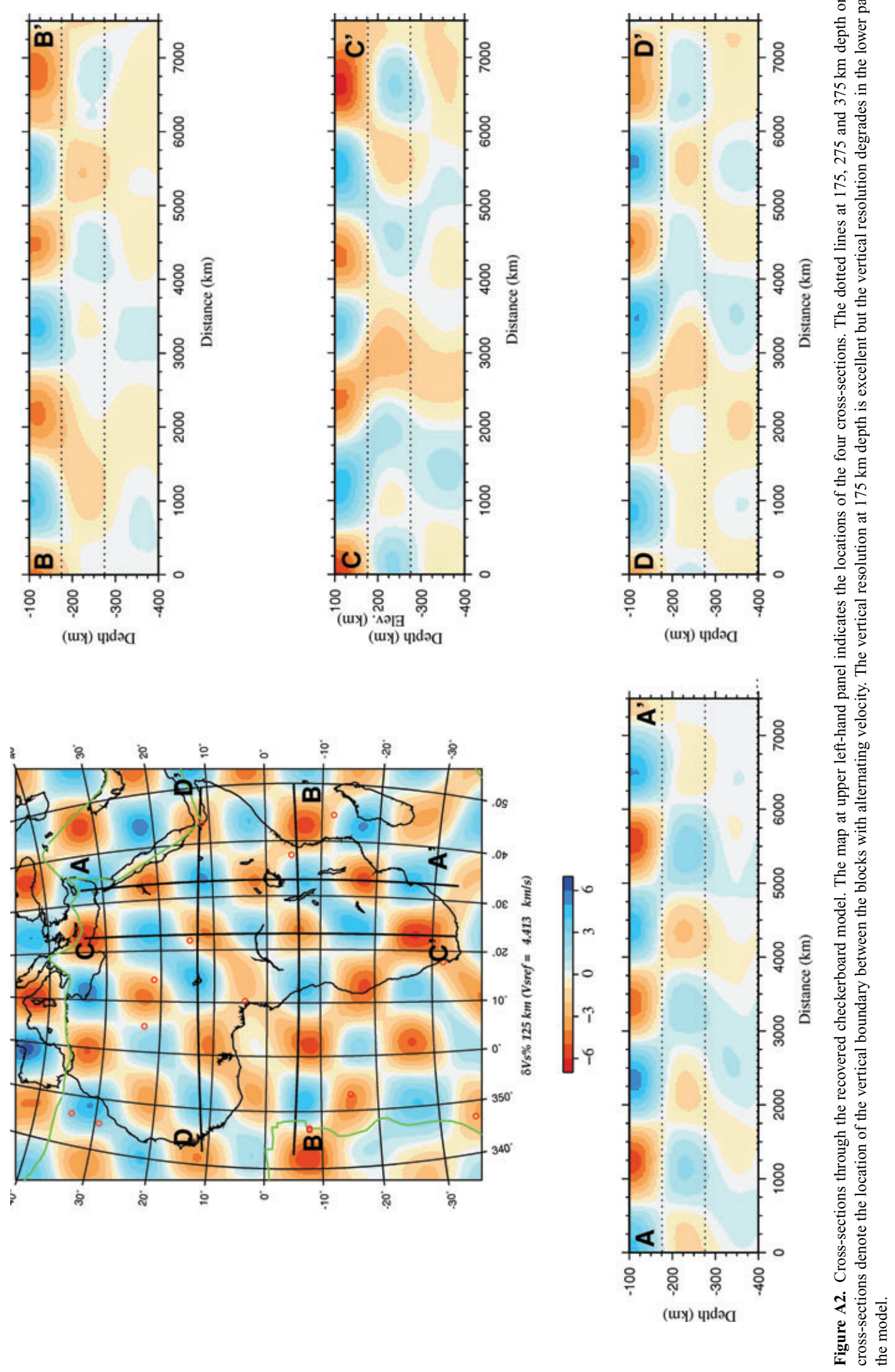


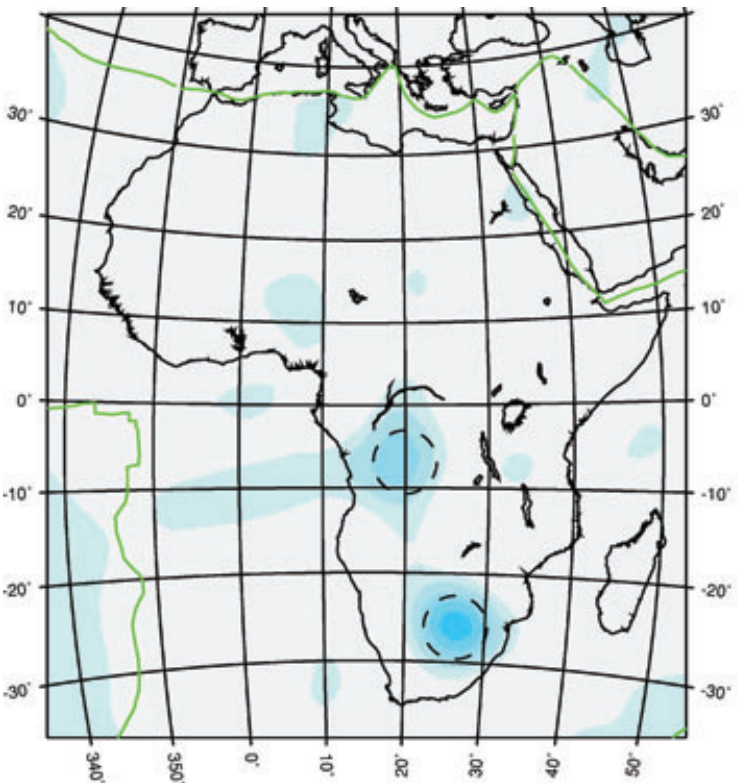

$150 \mathrm{~km}$

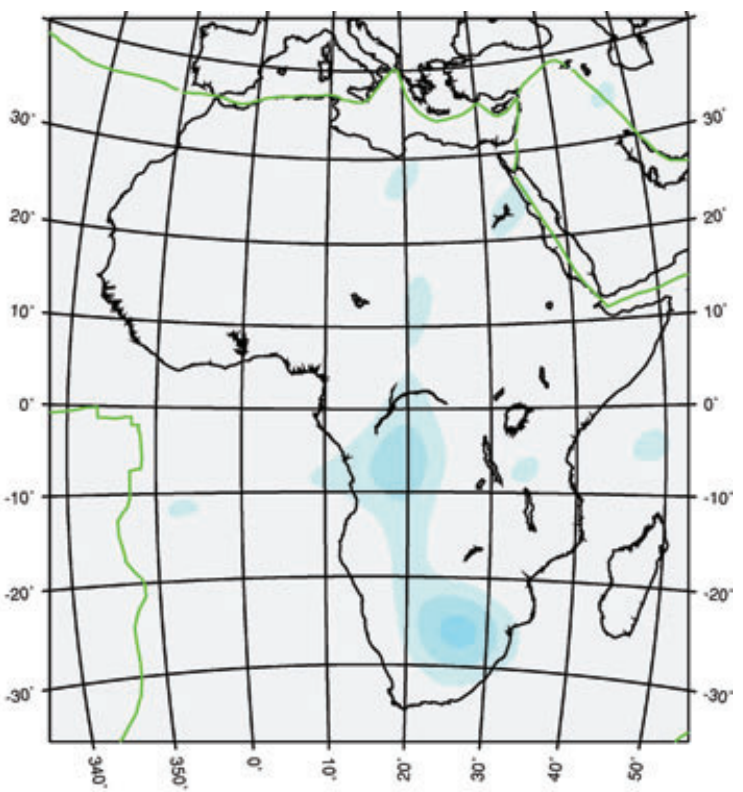

$200 \mathrm{~km}$

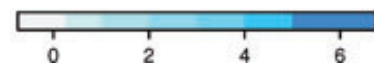

Figure A3. Results of a second synthetic resolution test in which we insert two 750-km-diameter, 200-km-thick discs, having a 5 per cent positive velocity perturbation, centred at $7.5^{\circ} \mathrm{S}, 20^{\circ} \mathrm{E}$ and $27.5^{\circ} \mathrm{S}, 27.5^{\circ} \mathrm{E}$ (dashed circles in $150 \mathrm{~km}$ map). The result at $150 \mathrm{~km}$ depth shows substantial smearing of the high anomaly, centred at $7.5^{\circ} \mathrm{S}, 20^{\circ} \mathrm{E}$ westward into the Gulf of Guinea but minimal smearing occurs at $200 \mathrm{~km}$ depth.

provides insights on the spatial resolution of the 3-D model attained from the path coverage but also yields information on the depth resolution achieved from the frequency and modal content of the seismograms analysed.

Fig. (A1) shows slices through the recovered checkerboard model at the same depths as given for the model in Fig. 4. Fig. (A2) shows cross-sections through the recovered checkerboard model along four paths through the model, chosen to assess the depth resolution for particular geologic features. The geometry of the input model is retrieved over the whole depth range. The transition depth between the first and second layer of blocks is accurate to $\pm 10 \mathrm{~km}$ and the depth between the second and third layer of blocks is accurate to $\pm 25 \mathrm{~km}$. At shallow depths, the amplitude of the input model is faithfully recovered, but at $250 \mathrm{~km}$ depth, the amplitude recovery is $\sim 50$ per cent of the input amplitude. At $400 \mathrm{~km}$ depth (not shown in Fig. A1), the amplitude recovery drops to $\sim 30$ per cent of the input amplitude. The recovery of the checkerboard model does not appear as good as in the checkerboard test shown for some studies in the literature that use fewer surface wave paths and only fundamental mode data. This is because we have clustered the path-average model to form average models with larger but more realistic errors. The checkerboard recovery would appear to be better if we had used the individual path-average model, with the a posteriori error for these derived from the first stage of the analysis. From this checkerboard test, we conclude that the vertical resolution of our model is $\sim 50$ $\mathrm{km}$ or better, to $400 \mathrm{~km}$ depth. However, the amplitude recovery of anomalies degrades with depth.

Fig. (A3) shows the results of a second resolution test in which we insert two $750-\mathrm{km}$-diameter, $200-\mathrm{km}$-thick plates, having a 5 per cent positive velocity perturbation centred at $7.5^{\circ} \mathrm{S}, 20^{\circ} \mathrm{E}$ and $27.5^{\circ} \mathrm{S}, 27.5^{\circ} \mathrm{E}$ into the reference mantle model with a $3 \mathrm{SMAC}$ crust. Synthetic seismograms were computed that correspond to the real seismograms for this part of the model, and these were inverted in the same manner as were the actual ones. Fig. A3 shows substantial smearing of the high velocity anomaly centred at $7.5^{\circ} \mathrm{S}, 20^{\circ} \mathrm{E}$ westward into the Gulf of Guinea at $150 \mathrm{~km}$ depth but reduced smearing at $200 \mathrm{~km}$ depth. It also demonstrates that there is some smearing between the two plates representing the Congo and Kalahari Cratons (Fig. A3) in southern Africa. The results of this test suggest that the high velocity feature of the model beneath the Gulf of Guinea may be an artefact of the poor path coverage in this area.

Fig. (A4) shows a lid resolution test for our model in the vicinity of the Congo Basin. Synthetic models were created to simulate a region of the mantle with no lid structure, surrounded by mantle with a thick, high velocity lid. This structure simulates the mantle structure proposed by Pasyanos \& Nyblade (2007) to exist beneath the region surrounding Congo Basin. Each synthetic model consisted of a 4 per cent positive annulus superimposed on the reference model. In the first test, the outer diameter of the annulus was $2000 \mathrm{~km}$ and the inner diameter was $1000 \mathrm{~km}$, similar in size to the Congo Basin. In the second test, the outer and inner diameter were 1250 and $750 \mathrm{~km}$, respectively, and in the third test, the outer and inner diameter were 1000 and $500 \mathrm{~km}$, respectively. In each case, the annulus was 200 $\mathrm{km}$ thick. The results of the tomographic inversions are shown at two depths, 125 and $150 \mathrm{~km}$. These tests suggest that the resolution in this part of our model is sufficient to detect the type of structure beneath the Congo Basin, proposed by Pasyanos \& Nyblade (2007), if it existed, and its diameter was as small as $750 \mathrm{~km}$. 

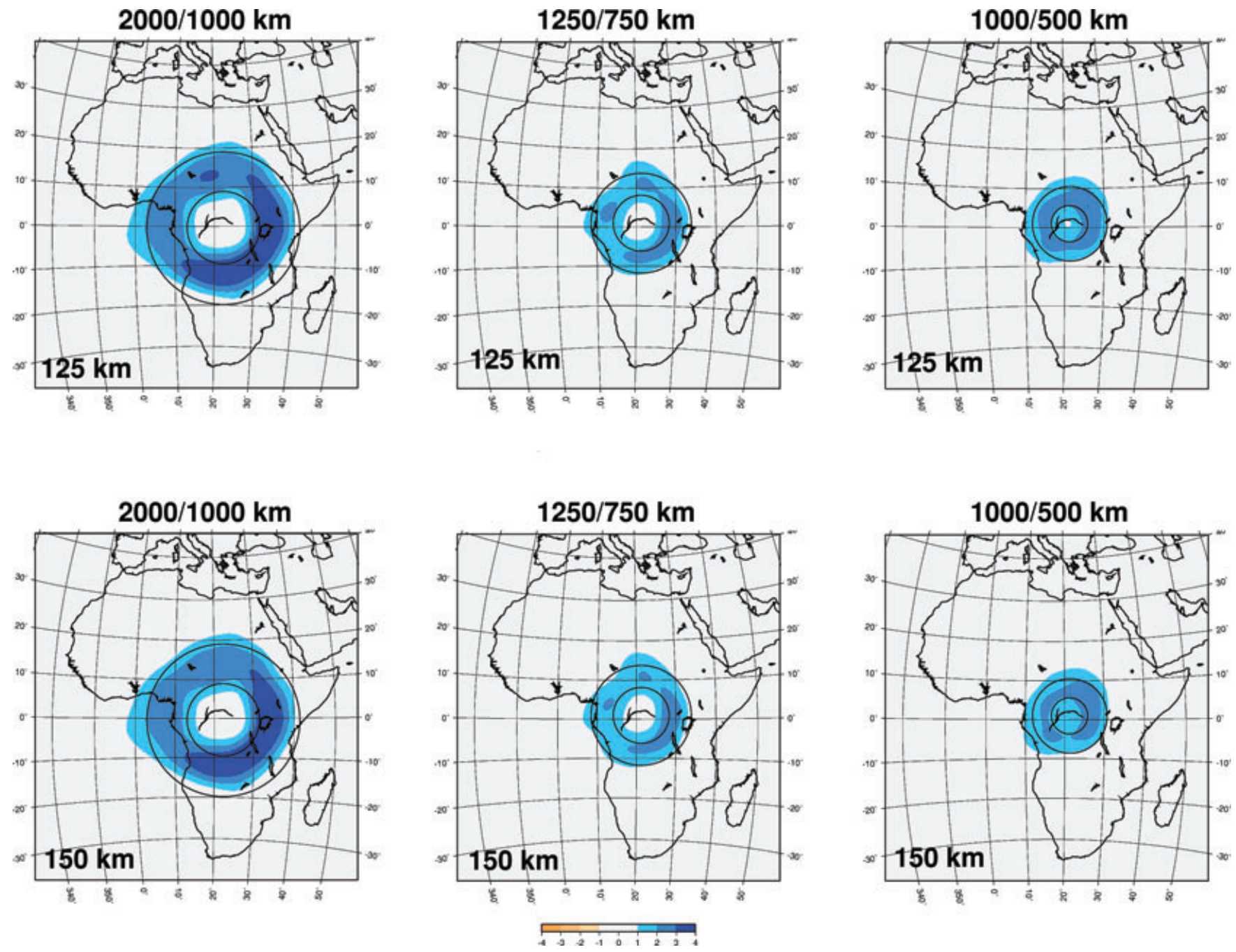

Figure A4. Lid resolution test for the Congo Basin. The outer and inner diameter of the annulus is given at the top of each plot, and the depth is given in the lower left-hand corner of each plot. 